\title{
JOAQUINA COMELLA, AUTORA DESCONOCIDA DE LOS LIBRETOS PARA SIETE TONADILLAS DE BLAS DE LASERNA
}

\author{
Joaquina Comella, Unacknowledged Author \\ of the Libretti for Seven "Tonadillas» by Blas de Laserna
}

\author{
María Jesús GARCÍA GARROSA \\ Universidad de Valladolid \\ mjesus@fyl.uva.es
}

Fecha de recepción: 15/12/2014

Fecha de aceptación definitiva: 29/09/2015

RESUMEN: El punto de partida de este trabajo es el descubrimiento de documentación que identifica a Joaquina Comella (¿1778?-1800) como autora de siete libretos para tonadillas del compositor Blas de Laserna: las solicitudes de licencia de representación de siete «Tonadillas a tres» cursadas en 1800. La investigación subsiguiente ha deparado la localización de dos de esos libretos - de uno de los cuales, $L a$ pasiega y el hidalgo, se ofrece aquí una edición crítica- y ha permitido reconstruir la vida textual, musical y escénica de cinco de las siete piezas aludidas a través de las partituras y los apuntes teatrales conservados. Como resultado, contamos ahora con un corpus amplio y homogéneo con el que abordar el estudio de la producción de una autora de la que hasta ahora solo se conocía una creación y que testimonia su amplia colaboración con Laserna. El análisis de las obras que completa este artículo, enfocado desde una perspectiva filológica, pone de relieve las dotes de Joaquina Comella para la composición dramática en este género musical, con lo que se quiere contribuir a una mejor valoración del componente literario de la tonadilla escénica dieciochesca.

Palabras clave: Joaquina Comella; Blas de Laserna; siglo XVIII; tonadillas escénicas; libretos; licencias de representación; La pasiega y el hidalgo. 
ABSTRACT: The starting-point of this study is the discovery of documents which identify Joaquina Comella (c. 1778-1800) as the author of seven libretti for tonadillas whose music would be composed by Blas de Laserna. The documents are requests for permission to perform seven works for three voices which were submitted in 1800. The discovery has led to the tracking down of two of the libretti, one of which, La pasiega y el hidalgo (The woman from Pas and the nobleman), is presented here in a critical edition. The ensuing research has involved the reconstruction of the textual, musical and performance possibilities of five of these works by analysing the texts in conjunction with theatre notes and musical scores. As a result we now have a considerable homogeneous body of work on which to base a study of the output of an author for whom until now only one libretto was extant; it also provides substantial evidence of Comella's partnership with Laserna. The literary analysis which forms the complementary focus of this study highlights the quality of Joaquina Comella's dramatic talent in the musical genre in question and aims to enrich the evaluation of the literary component of $18^{\text {th }}$-century tonadillas designed for dramatic performance.

Key words: Joaquina Comella; Blas de Laserna; Eighteenth Century; Dramatic musical sketches (tonadillas); Libretti; Licences to Perform; La pasiega y el hidalgo (The woman from Pas and the nobleman).

\section{INTRODUCCIÓN}

A pesar de la amplitud de la producción conservada, la tonadilla escénica es una forma dramático-musical que no ha suscitado un gran interés entre los investigadores en su aspecto literario. En este sentido, en su esclarecedor estado de la cuestión sobre los estudios en torno a la tonadilla dieciochesca, Begoña Lolo apuntaba a la propia esencia del género, a su inmediatez y carácter efímero, y a la escasa huella documental dejada en su época como factores determinantes para «establecer una valoración correcta del género posteriormente, que ha llevado a considerarlo completamente irrelevante para el ámbito literario" ${ }^{1}$; una estimación a la que habría contribuido también, como sugirió Alberto González Troyano, la supremacía concedida al componente musical de las tonadillas, que deja en segundo plano la parte literaria de las mismas, el libreto, "como un mero aporte subsidiario de la música»².

El desconocimiento de la identidad de los autores de la mayoría de los libretos conservados ha contribuido a reforzar esta idea de la escasa calidad de unos

1. Lolo, Begoña. "La tonadilla escénica, ese género maldito». Revista de Musicología, 2002, XXV, n. ${ }^{\circ} 2$, p. 452.

2. González Troyano, Alberto. "En torno a la tonadilla escénica». En Álvarez Barrientos, Joaquín y CHECA Beltrán, José (eds.). El siglo que llaman ilustrado. Homenaje a Francisco Aguilar Piñal. Madrid: CSIC, 1996, p. 487. Véase también HuERTAS, Eduardo. "La tonadilla escénica». En Teatro musical en el Madrid ilustrado. Madrid: Avapiés, 1989, p. 53. 
textos compuestos por "oscuros creadores de piececillas sin trascendencia" ${ }^{3}$, que sabían que "no era preciso prodigar primores" ${ }^{4}$ en unas obras destinadas al canto, de vida efímera y exigua retribución. El anonimato sería así una confirmación de la pobre consideración de un trabajo que el músico pagaba a quien más barato ofreciera unos textos poco elaborados literariamente ${ }^{5}$, y parece haber asentado la creencia «de que nos encontrábamos ante repertorios de autores de muy poca importancia o bien ante obras de consumo de escasa calidad, en las que primaba la inmediatez frente a cualquier otro tipo de planteamiento, de ahí que su creador no quisiese reconocer la paternidad del texto" ${ }^{6}$.

Este prejuicio que liga anonimato a escaso valor literario en una producción que solo adquiere sentido al servicio de la música no alienta, desde luego, muchas investigaciones desde la perspectiva filológica, e impide, como apunta Begoña Lolo $^{7}$, enmarcar el estudio de los libretos para tonadillas en el conjunto de la producción de determinados autores, lo que contribuiría a una visión más pertinente de temas, recursos y estilos de sus composiciones tonadillescas.

Así pues, uno de los retos en la investigación sobre las tonadillas escénicas dieciochescas es el del descubrimiento de los nombres de quienes colaboraron con los grandes compositores del género. Y ello no tanto para confirmar que algunos de esos textos sin firma salieron probablemente de las plumas de reconocidos dramaturgos dieciochescos ${ }^{8}$, sino porque la adjudicación de un corpus relativamente importante a un autor concreto permitiría profundizar en el análisis de sus técnicas compositivas y tal vez, si es el caso, de la relación creativa entre libretista y músico cuando esta colaboración fue continuada.

El objeto de este trabajo es precisamente dar a conocer el hallazgo de documentación que revela la autoría de siete libretos para tonadillas del compositor Blas de Laserna, obra de Joaquina Comella, que había colaborado con el músico navarro en La Anita, la única composición de la autora de la que hasta ahora se tenía testimonio. La localización de cinco de esos textos da ocasión para un estudio más detallado de parte de ese riquísimo corpus de tonadillas escénicas conservadas, especialmente enfocado desde la perspectiva filológica tan desatendida, y nos acerca a la figura literaria, ahora más perfilada, de la hija del dramaturgo Luciano Francisco Comella.

3. SubIRÁ, José. La tonadilla escénica. Tomo II. Morfología literaria. Morfología musical. Madrid: Tipografía de Archivos, 1929, p. 283.

4. SubIrá, José. La tonadilla escénica. Sus obras y sus autores. Madrid: Labor, 1933, p. 87.

5. Véase sobre este tópico González Troyano, Alberto. "En torno a la tonadilla escénica», p. 489.

6. "La tonadilla escénica, ese género maldito», p. 449.

7. Ibid., pp. 449-450.

8. Puede verse el nombre de algunos de los libretistas identificados (Luciano Comella, Ramón de la Cruz, Tomás de Iriarte, Gaspar Zavala y Zamora, Luis Moncín, entre otros) en SuBIRÁ, José. La tonadilla escénica. II, pp. 24-28, y más recientemente en LoLO, Begoña. "La tonadilla escénica, ese género maldito", p. 449. 


\section{JOAQUiNA COMELLA}

Lo que sabemos de Joaquina Comella Beyermón procede más de la ficción literaria que de los archivos: en la doña Mariquita de La comedia nueva que compone coplas y estudia gramática por indicación de su hermano don Eleuterio estaría parodiada la hija mayor de Luciano Comella, que se quejó ante varias instancias oficiales para impedir la representación de la sátira que, a su parecer, Leandro Moratín hacía de su familia. Casi un siglo más tarde, en La Corte de Carlos IV, Benito Pérez Galdós volvería a hacer burla de Comella y de su hija, de su miseria y del trabajo literario de "la jorobadita", que ayudaba a su padre componiendo escenas para sus comedias heroicas?.

Es esta imagen literaria la que ha acabado imponiéndose a la de la Joaquina Comella real, quizá porque de esta el único dato confirmado parece ser la fecha de su muerte, el 25 de noviembre de 1800, a los veintidós años, en Madrid, y su entierro en la iglesia de San Sebastián, según consta en su partida de defunción ${ }^{10}$. De su buen hacer como versificadora y de la colaboración con su padre en las tareas literarias son muchos estudiosos del teatro dieciochesco los que dan cuenta ${ }^{11}$, pero sin más evidencia que ese "mito" literario y una cita de Cotarelo, al que casi todos remiten. Alude don Emilio al testimonio, en 1802, del actor Manuel García Parra, según el cual, «aquella jorobadilla [...] no solo le ayudaba a componer, sino que también ella escribió algunas obras que se representaron en los teatros de Madrid" ${ }^{12}$.

En efecto, Manuel García refiere que «en los tiempos presentes hemos visto composiciones dadas a los mismos [nuestros teatros] por doña Gabriela Morón, doña Rosa de Gálvez, y aun de doña Joaquina Comella, hija del actual don Luciano» ${ }^{13}$. El testimonio del actor coetáneo de los Comella tiene el interés de

9. Véase, entre otros, Angulo EgEA, María. «Una tonadilla escénica. La Anita de Joaquina Comella, con música de Blas de Laserna». Salina, 12, 1998, pp. 77-99, que da cumplida información sobre esta imagen literaria.

10. La reproduce Cotarelo y Mori, Emilio. Iriarte y su época [1897]. Santa Cruz de Tenerife: Artemisa, 2006, p. 451.

11. "Dícese que Joaquina le ayudaba a componer sus dramones, y aun que llegó a escribir por su cuenta algunas obras", escribe SERRANO y SANZ, Manuel. Apuntes para una biblioteca de escritoras españolas desde el año 1401 al 1833. I. Primera parte [1903]. Madrid: Atlas, 1975, p. 275. "Joaquina se distinguió precozmente como fácil versificadora, por lo que ayudó a don Luciano en la confección de sus producciones teatrales». SuBIRÁ, José. Un vate filarmónico: Don Luciano Comella. Madrid: Real Academia de Bellas Artes de San Fernando, 1953, p. 9. Puede verse también Herrera Navarro, Jerónimo. Catálogo de autores teatrales del siglo XVIII. Madrid: Fundación Universitaria Española, 1993, pp. 123124; GRINSTEIN, Julia Bordiga. "Panorama de la dramaturgia femenina española en la segunda mitad del siglo XVIII y principios del XIX". Dieciocho, 2002, 25. 2, p. 198; PAlaCios FernándeZ, Emilio. La mujer y las letras en la España del siglo XVIII. Madrid: El Laberinto, 2002, pp. 196 y 227.

12. Iriarte y su época, p. 451.

13. García de Villanueva Hugalde y ParRa, Manuel. Origen, épocas, y progresos del teatro español. Madrid: Gabriel de Sancha, 1802, p. 318. 
confirmar la llegada a los escenarios de la obra dramática de Joaquina Comella, de la obra propia, aunque no precise cuándo ni la amplitud de esa producción. Hasta ahora solo se tenía constancia de la composición y estreno de una obra de la hija mayor de Luciano Comella: su tonadilla a tres La Anita, con música de Blas de Laserna, escrita en 1794 y probablemente representada en febrero de ese año, a juzgar por las fechas de las aprobaciones que constan en el manuscrito conservado ${ }^{14}$. Sería la creación de una joven de unos catorce años, y, como bien apunta Fernando Doménech, no parece lógico «que la autora dejara de componer después ${ }^{15}$.

Y así fue. Joaquina Comella siguió componiendo hasta su temprana muerte, como revelan los documentos y textos que he localizado, que confirman lo que fue algo más que una colaboración puntual, en 1794, con el músico Blas de Laserna, y que dan cuenta de una actividad literaria más sólida y continuada de la autora, como se suponía.

\section{LAS SOLICITUDES DE LICENCIA DE REPRESENTACIÓN}

Una de las dificultades para la identificación de los autores de los libretos de las tonadillas es que ni este dato ni el propio título de la obra solían especificarse en los pagos de cuentas presentados por las compañías y registrados en el Archivo de la Villa de Madrid ${ }^{16}$. Por ello, las solicitudes de licencia de representación y los informes de los censores resultan en este género en particular una fuente de información de primer orden. En el caso de la producción dramática de Joaquina Comella son esos documentos, hasta ahora desconocidos, los que han permitido su reconocimiento como autora de varios libretos de tonadillas ${ }^{17}$.

En el Archivo Histórico Diocesano de Madrid se conservan cinco documentos con solicitudes de licencia de representación de siete "tonadillas a tres» compuestas por Blas de Laserna de cuyos libretos es autora Joaquina Comella. Las solicitudes se presentaron ante el Vicario Eclesiástico de Madrid entre agosto y diciembre de $1800^{18}$. El texto de las mismas y las censuras de que fueron objeto pueden leerse en el Apéndice 2 de este trabajo, pero una presentación sucinta nos permitirá hacer aquí un análisis de los datos que ofrecen.

14. Véase Angulo EgeA, María. "Una tonadilla escénica. La Anita...", pp. 87-88. La Anita ha sido editada por Doménech, Fernando en Teatro breve de mujeres. Siglos XVII-XX. Madrid: Asociación de Directores de Escena de España, 1996, pp. 116-135, con un análisis previo en pp. 104-113.

15. "Comella, Joaquina». En Hormigón, Juan Antonio (dir.). Autoras en la historia del teatro español (1500-1994). Volumen I (Siglos XVII-XVIII-XIX). Madrid: Asociación de Directores de Escena de España, 1996, p. 433.

16. Lolo, Begoña. "La tonadilla escénica, ese género maldito", p. 451

17. Así sucedió también con el manuscrito de La Anita conservado en la Biblioteca Nacional, cuya autoría revela la censura de Santos Díez González.

18. Las solicitudes se encuentran en la Caja 9187, en documentos sin numerar. 
Las solicitudes presentadas al trámite censorio son escuetas y anuncian la intención de cantar en el teatro de la Cruz, de cuya compañía era compositor musical Blas de Laserna desde $1779^{19}$, siete tonadillas a tres, fruto de la colaboración del músico y Joaquina Comella. Los manuscritos parecen de mano de Joaquina, salvo el de la última solicitud, presentada por Laserna tras su fallecimiento, que es de letra distinta. El hecho de consignar su nombre y firmar ella en segundo lugar, además de rasgos de escritura que revelan las propias firmas y que pueden cotejarse con documentos autógrafos de Laserna lo confirmaría ${ }^{20}$. En todo caso, los cuatro primeros manuscritos revelan la escritura ágil y suelta de alguien acostumbrado al manejo de la pluma y a la redacción de este tipo de escritos.

La primera tonadilla para la que se solicita licencia de representación, el 21 de agosto de 1800, es El novio y las dos hermanas. El manuscrito se envía a la revisión de Pedro Estala, que realizará este y todos los informes de censura de los libretos de Joaquina Comella en los meses siguientes. Como era frecuente en el caso de obras breves, el censor redactaba en un mismo documento su informe sobre varios títulos, y Estala revisa el mismo día 21 la tonadilla y un sainete de Félix Hernández de Cubas, Los hidalgos chasqueados. Se autoriza la representación de la tonadilla, omitiendo lo rayado, el 22 de agosto de $1800^{21}$. No se conserva este libreto entre la documentación del Archivo Histórico Diocesano de Madrid que he revisado, por lo que no podemos saber cuáles eran las partes que debían suprimirse.

Diez días después, el 2 de septiembre, Joaquina Comella y Laserna presentan al Vicario Eclesiástico un nuevo escrito pidiendo licencia para cantar la tonadilla El marido indiscreto. El texto se remite a Estala junto con el del sainete El padre forzado, de Manuel José Blanco. El censor, en informe del día 9, considera ambas obras escandalosas e indignas de la escena, y en consecuencia, no se otorga a ninguna la licencia solicitada.

La actividad de la pareja Joaquina Comella y Laserna continúa a ritmo regular, y dos semanas después, el 17 de septiembre, solicitan licencia para cantar en el teatro de la Cruz una nueva obra, El novio simple. Estala firma esta vez un informe sin objeciones a su representación, por lo que se concede licencia el día 20.

19. Sobre la carrera de Blas de Laserna y su trabajo como compositor en las compañías de Martínez, en el Príncipe, y de Eusebio Ribera, en el teatro de la Cruz, véase Gómez, Julio. "Don Blas de Laserna. Un capítulo de la historia del teatro lírico español visto en la vida del último tonadillero». En Arrese, José Luis. Biblioteca de corellanos ilustres. Tomo V. El músico Blas de Laserna. Corella, 1952, pp. 119-163, así como la interesante documentación aportada en las pp. 165-185, entre la que figura la reproducción de algún autógrafo del músico.

20. La letra de estos documentos que atribuyo a Joaquina Comella tiene rasgos muy similares a los del manuscrito de La Anita, pero el carácter autógrafo de este último es un extremo que requeriría un estudio más profundo.

21. Las aprobaciones, en este y en los demás documentos que citaré, van sin firma, con un "Despachada corriente», o fórmula similar, y la fecha. 
También supera sin problemas el trámite censorio la tonadilla El majo y los dos hermanos, presentada el 30 de septiembre, cuya representación se autoriza el 6 de octubre, tras el informe de Estala de esa misma fecha.

Joaquina Comella murió el 25 de noviembre de ese año de 1800, dejando compuestos, a lo que parece, algunos libretos para Laserna. Pocos días después de su fallecimiento, el 2 de diciembre, es el músico quien presenta la solicitud de licencia para representar tres piezas, La pasiega y el hidalgo, El marido pesado y La elección de moda, "[habiendo] compuesto las letras doña Joaquina Comella (ya difunta)». Los manuscritos son remitidos el 3 de diciembre a Pedro Estala, que informa favorablemente, aunque en el documento no consta la aprobación del Vicario de Madrid.

Además del dato capital de confirmar la autoría de siete libretos de tonadillas en la figura de Joaquina Comella, estos documentos aportan, indirectamente, más información. Todas las solicitudes corresponden a un periodo muy breve de tiempo, están muy concentradas en apenas tres meses, indicando una actividad intensa en este momento tanto de la libretista como del compositor ${ }^{22}$. Solo la muerte de la joven dramaturga frenó lo que parecía una colaboración continuada y fructífera. Sabemos de la estrecha relación personal y profesional entre Blas de Laserna y Luciano F. Comella ${ }^{23}$; en ese ambiente familiar surgió sin duda la colaboración entre el músico y la jovencísima Joaquina, que se materializó en 1794 en La Anita, y que -ahora podemos constatarlo- se prolongó en el tiempo, lo cual dice mucho de la confianza del mejor músico teatral de la España de finales del siglo XVIII en la capacidad creativa de la joven escritora.

Ese es quizá uno de los datos más relevantes que ofrecen estas censuras: ponen una fecha de conclusión a una actividad literaria propia que se inició probablemente en 1794 con la redacción de La Anita, y que entre esa fecha y 1800 no tuvo por qué interrumpirse, sino que podemos suponer constante y regular. Además de las aspiraciones literarias de la hija mayor de Luciano Comella, los 60 reales que solía pagar el músico por cada libreto de tonadilla ayudarían a la precaria economía familiar ${ }^{24}$.

22. Conviene recordar el elevado número de tonadillas que los compositores de los teatros madrileños debían entregar cada año a las compañías. A finales de los años setenta, por ejemplo, los contratos de Laserna o de Pablo Esteve les obligaban a componer 62 tonadillas por temporada, a las que había que añadir las que les pedían los propios cantantes. Las cifras eran muy similares dos décadas después. Véase Gómez, Julio. "Don Blas de Laserna...”, pp. 131-135 y 180-181.

23. Subirá, José. Un vate filarmónico, pp. 10-33. Véase también Angulo EgEA, María. Luciano Francisco Comella (1751-1812). Otra cara del teatro de la Ilustración. Alicante: Universidad de Alicante, 2006.

24. Es la cantidad que Laserna se comprometió a pagarle en 1784 a la actriz Polonia Rochel por cada libreto de tonadilla que ella le entregase. Gómez, Julio. "Don Blas de Laserna...”, pp. 134 y 174. Por su parte, Jerónimo HERRERA NAVARRo estima en 80/100 reales el precio pagado por una tonadilla entre 1762-1800. "Precios de piezas teatrales en el siglo XVIII (Hacia los derechos de autor)». Revista de Literatura, 1996, LVIII, 115, p. 68. 
Así pues, parece razonable pensar que Joaquina Comella siguió componiendo entre 1794 y 1800, y que de su pluma saldrían en esos años más libretos para Laserna que los que atestiguan las solicitudes ahora descubiertas. Parece que Joaquina Comella se especializó en la modalidad de tonadillas a tres, aunque no hay que descartar que la dramaturga compusiera otras obras más extensas y de otros géneros para el músico navarro.

\section{Evidencias documentales: Libretos, Partituras y Apuntes teatrales}

¿Qué suerte han corrido estas siete tonadillas a tres, los últimos frutos literarios de Joaquina Comella? La investigación posterior al descubrimiento de las licencias de representación ha intentado reconstruir la vida textual, musical y escénica de los siete títulos, con distinta fortuna, según el caso.

En síntesis, estos son los resultados. Los libretos de dos tonadillas, El marido indiscreto y La pasiega y el hidalgo, se han conservado en el propio Archivo Histórico Diocesano de Madrid. De estas obras hay también apuntes teatrales, es decir, los textos dramáticos con las indicaciones para su puesta en escena, en la Biblioteca Histórica Municipal de Madrid, donde se localizan igualmente los apuntes de teatro de El novio y las dos hermanas y El marido pesado, mientras el de El majo y los dos hermanos se halla en la Biblioteca Nacional de España. Las partituras de Laserna de estas cinco tonadillas se encuentran entre los fondos de la Biblioteca Histórica Municipal de Madrid. No he podido localizar ningún documento ni del texto ni de la música de las dos obras restantes, El novio simple ${ }^{25}$ y La elección de moda ${ }^{26}$.

El marido indiscreto y La pasiega y el hidalgo son las tonadillas que han dejado una huella escrita más rica, pues se conservan los tres documentos que remiten a su creación literaria, el libreto, y musical, la partitura, así como a su representación, el apunte teatral.

El libreto de La pasiega y el hidalgo ${ }^{27}$, de letra diferente a la de la solicitud de licencia para su representación, consta de 7 hojas encabezadas por el título

25. Existe una tonadilla de Laserna de título El novio simple y las dos hermanas, pero no puede tratarse de esta escrita por Joaquina Comella en 1800, pues se estrenó en el Príncipe el 31 de mayo de 1787. Véase ANDIOC, René y COUlOn, Mireille. Cartelera teatral madrileña del siglo XVIII (1708-1808). Madrid: Fundación Universitaria Española, 2008, 2. ${ }^{a}$ ed., II, p. 806.

26. No se recogen a nombre de Blas de Laserna partituras o apuntes teatrales con esos títulos ni en los fondos de la Biblioteca Histórica Municipal ni en la Biblioteca Nacional. Tampoco figuran entre los títulos atribuidos al músico navarro en los repertorios de SuBIRÁ, José. La tonadilla escénica. Tomo I. Concepto, fuentes y juicios. Origen e bistoria. Madrid: Tipografía de Archivos, 1928, pp. 352359, Gómez, Julio. "Don Blas de Laserna...", pp. 186-208, o BARBIERI, Francisco A. Documentos sobre música española y epistolario. Ed. CASAREs, Emilio. Madrid: Fundación Banco Exterior de España, vol. 2, 1988, pp. 1157-1167.

27. AHDM, Caja 9186. 
y la indicación de que está destinada a la Compañía del Señor Navarro, esto es, al teatro de la Cruz. Como era frecuente, los personajes son designados con los nombres de los actores para los que se había pensado la composición: Querol (Hidalgo), Joaquina (Pasiega), Manuela (Beata).

El apunte teatral ${ }^{28}$ de esta tonadilla reproduce, con algunas variantes, el texto del libreto, con las repeticiones de versos que habían de servir de pauta a los cantantes y algunas indicaciones escénicas ${ }^{29}$. No tiene fecha, ni referencia a los actores que habían de interpretarla, sino que figuran los personajes: el Hidalgo, la Pasiega y la Beata.

También en la Biblioteca Histórica Municipal de Madrid se conserva la partitura de esta tonadilla ${ }^{30}$. Lleva, como todas las demás, el nombre de Laserna, y un reparto para el año 1801, que no coincide con el del libreto: Pasiega: Sra. Joaquina, Beata: Sra. Puig e Hidalgo: Sr. Eusebio. Las partichelas recogen la anotación musical para dos violines primeros y dos segundos, una viola, oboes primero y segundo, un clarinete, trompas primera y segunda, un fagot y dos bajos ${ }^{31}$. La parte textual se corresponde más con el apunte que con el libreto, y se han incorporado nuevas indicaciones escénicas.

El libreto de la tonadilla El marido indiscreto también ha permanecido en el Archivo Histórico Diocesano de Madrid, junto con la solicitud de licencia de representación que, recordemos, le fue denegada ${ }^{32}$. De ello deja constancia el manuscrito, en cuya primera hoja se ha escrito "Reprobada». Ocupa 6 hojas, copiadas por dos manos diferentes: la primera parece la misma del libreto de La pasiega y el hidalgo; a partir del último verso del folio 4v se aprecia otra caligrafía, muy semejante a la de la solicitud de licencia, que, como se ha indicado, supongo autógrafa de Joaquina Comella. Compuesta para su representación en el coliseo de la Cruz, también aquí, en lugar de los personajes, aparece el nombre de los actores: Eusebio (Marido), Camas (Abogado) y Genoveva (Mujer).

A pesar de la reprobación, la tonadilla debió de estrenarse, como prueba el apuntamiento primero de la Biblioteca Histórica Municipal ${ }^{33}$. La censura negativa de Estala explica que el texto de este manuscrito difiera en algunos puntos esenciales del presentado en el libreto. El reparto, en cambio, es el mismo que el pensado en un principio para su representación en el teatro de la Cruz. La partitura $^{34}$, con fecha de 1800 y el nombre de Laserna, lleva también este reparto:

28. BHM, Tea 222-150

29. Es una práctica habitual en los apuntamientos de tonadillas, por lo que no insistiré en este punto en los documentos que iré presentando seguidamente.

30. BHM, Mus 125-1.

31. Salvo indicación contraria, la música de las restantes tonadillas está compuesta para los mismos instrumentos.

32. AHDM, Caja 9187.

33. BHM, Tea 1-199-37.

34. BHM, Mus 118-13. 
Sra. Genoveva, Camas, y el Bajo, Eusebio, aunque se ha añadido en el margen superior derecho otro nombre, Sra. Carlota. Su texto es más próximo al del libreto reprobado que al del apunte teatral que conservamos.

Lamentablemente, no parece que hayan sobrevivido los libretos de las otras tres tonadillas escritas por Joaquina Comella, o al menos no he podido localizarlas junto con la documentación relativa a sus censuras en el Archivo Histórico Diocesano de Madrid. Más suerte ha habido con las partituras y los apuntes teatrales.

De El marido pesado y El novio y las dos hermanas se conservan los dos documentos en la Biblioteca Histórica Municipal. El texto de la partitura de El marido pesado ${ }^{35}$, con fecha de 1801, coincide con el del apunte teatral ${ }^{36}$, aunque con diferente emplazamiento para algunas partes musicales. El apunte, como la partitura, indica el nombre de los cantantes en el lugar de los personajes: Lorenza (Mujer), Eusebio (Marido) y Riva (Maestro de música).

La partitura de El novio y las dos hermanas ${ }^{37}$ lleva fecha de 1800, y un reparto con los nombres, tachados, de Sra. Lorenza, Sra. Briones y Sr. Riba, que son los que designan a los personajes (salvo el de Novio, que no aparece aún asignado a Juan Rivas) en el cuerpo de la partitura, lo que indicaría un estreno en esa temporada. Junto a estos nombres se ha escrito el de Sra. Martina, que coincide con el del apunte teatral. En efecto, el apunte de esta tonadilla ${ }^{38}$ es una copia de 1803 del texto de la obra para la actriz Martina Iriarte, en Zaragoza, como indica la primera hoja, aunque el manuscrito conserve los nombres de quienes harían en Madrid en 1800, fecha de la partitura, el papel de las dos hermanas: la Briones y Lorenza. Además de este cambio de reparto (que constata, como en otros casos, que una tonadilla podía cantarse en varias ocasiones, y en varios teatros), hay que señalar que en este caso la partitura contiene un texto muy diferente al del apunte conservado, lo que indicaría cambios de la letra de la obra en función de los cantantes o del momento y lugar de su representación ${ }^{39}$.

La partitura de El majo y los dos hermanos ${ }^{40}$, con fecha de 1800, es, en cambio, muy cercana textualmente al apunte teatral conservado en la Biblioteca Nacional $^{41}$, en el que figuran los nombres de Eusebio y Lorenza en el papel de los hermanos. El cuerpo de la partitura lleva esos mismos nombres, y el de Majo, sin asignar aún a ningún cantante, pero en su primera hoja se consigna el reparto siguiente: Sra. Carlota, Sr. Camas y Sr. Muñoz.

35. BHM, Mus 120-3.

36. ВНM, Тea 221-218

37. BHM, Mus 131-11.

38. ВНM, Tea 1-199-26.

39. No hay partichelas en esta obra para viola ni para clarinete.

40. BHM, Mus 131-8.

41. BN, Mss. 14066/29. 


\section{LA REPRESENTACIÓN}

Las solicitudes de licencia para cantar las cinco tonadillas de Joaquina Comella y Laserna de que ahora tenemos noticia están fechadas entre agosto y diciembre de 1800, es decir, en el año cómico 1800-1801. Sin embargo, parece que tardaron un tiempo en llegar a los escenarios; al menos las dos de cuyo estreno tenemos referencia, que lo hicieron en 1801, ya en la temporada 1801-1802.

El marido pesado se cantó en el teatro de la Cruz el 5 de abril de $1801^{42}$, día de inicio del año cómico, junto con la comedia de Calderón Antes que todo es mi dama, sin duda con el reparto que figura en el apunte teatral: Lorenza Correa, primera actriz para los papeles de cantado en el teatro de la Cruz, y Juan Rivas, llegado a esa compañía en la temporada anterior, en los papeles de Mujer y Maestro de música; y Eusebio Fernández, que actuaba en las dos compañías y era especialista en papeles de bufo, en el de Marido ${ }^{43}$.

Pocas semanas después, el 30 de mayo, se estrenó en el mismo teatro la tonadilla La pasiega y el hidalgo, con otra obra nueva, Clementina y Desormes, drama sentimental francés traducido por Vicente Rodríguez de Arellano ${ }^{44}$. El reparto tuvo que ser el que figura en la partitura para 1801: la cantante de carácter jocoso Joaquina Arteaga como la Pasiega, Eusebio Fernández como el Hidalgo, y María Puig, nueva ese año en la compañía del coliseo de la Cruz, en el papel de la Beata. El reparto que figura en el libreto, con (Mariano) Querol, Joaquina (Arteaga) y Manuela (probablemente Manuela Correa) responde más bien a la situación de las compañías madrileñas en la temporada anterior, cuando se compuso la tonadilla (presentada a censura, recordemos, en diciembre de 1800), y en cuyos cantantes pensarían la libretista y el músico ${ }^{45}$.

No constan más datos de representación para las tonadillas restantes de Joaquina Comella y Blas Laserna ni en la Cartelera teatral madrileña de Andioc y Coulon ni en la que recoge Cotarelo en Isidoro Máiquez y el teatro de su tiempo. Con todo, podemos rastrear la llegada a los escenarios de otra de ellas con datos indirectos.

Como hemos visto, El marido indiscreto no obtuvo el permiso para representarse en el teatro de la Cruz, a pesar de lo cual se conserva un apunte teatral, lo que indica la disposición para su puesta en escena. Tanto el libreto reprobado

42. Andioc, René y Coulon, Mireille. Cartelera teatral madrileña, I, p. 488.

43. Sobre los componentes de las compañías en las temporadas 1800-1801 y 1801-1802 puede verse Cotarelo y Mori, Emilio. Isidoro Máiquez y el teatro de su tiempo [1902]. Madrid: Asociación de Directores de Escena, 2009, pp. 518-524.

44. ANDIOC, René y COUlon, Mireille. Cartelera teatral madrileña, I, p. 488

45. Mariano Querol, por ejemplo, figuraba en la compañía de la Cruz en papeles jocosos en la temporada 1800-1801, pero en 1801-1802 estaba actuando, bajo la dirección de Isidoro Máiquez, en los Caños del Peral. Joaquina Arteaga y Manuela Correa estaban también en la temporada 1800-1801 en la Compañía de Luis Navarro, en el teatro de la Cruz. 
como este apunte designan a los mismos cantantes para los papeles de Marido (Eusebio), Abogado (Camas) y Mujer (Genoveva), que también son los que figuran en la partitura, fechada en 1800. Este reparto es exactamente el mismo que el que da Cotarelo para la representación, el 27 de septiembre de 1800 en el teatro del Príncipe, de la comedia La Holandesa, de Gaspar Zavala y Zamora. "Cantaron -añade Cotarelo- Camas, Eusebio y la Genoveva, nueva "46. Eusebio Fernández y Vicente Camas estaban en esa compañía en la temporada 1800-1801. ¿Quién es esta Genoveva, nueva? La respuesta la da el Diario de Madrid de ese 27 de septiembre: «[e]n la función de El Príncipe se pondrá La Holandesa, y cantará Genoveva Malliani, nueva en los teatros de esta Corte, con una tonadilla nueva». No parece arriesgado suponer que esa tonadilla nueva cantada por la Malliani en su debut madrileño es El marido indiscreto, cantada en el Príncipe en un momento (entre el 9 y el 30 de septiembre) en el que solo hubo funciones en ese teatro ${ }^{47}$.

En cuanto a las otras dos tonadillas, debieron de interpretarse en fecha cercana a su aprobación, es decir, entre agosto y diciembre de 1800, pues las partituras de ambas llevan fecha de 1800. El novio y las dos hermanas, aprobada el 22 de agosto, es quizá la tonadilla nueva que se anuncia en el Diario de Madrid para acompañar a la comedia Semíramis reconocida en la Cruz el 25 de ese mes, con Joaquina Briones (nueva, esa temporada, en la compañía del Príncipe) y Lorenza Correa como las dos hermanas, y Juan Rivas como el novio, según reza la partitura $^{48}$. Y El majo y los dos hermanos, aprobada el 6 de octubre, puede ser la tonadilla nueva que se anuncia el 14 para cantarse junto a la comedia Elisa y Clearco, con Lorenza Correa y Eusebio Fernández esta vez como los dos hermanos. Más problemático resulta aventurar una fecha de representación con el reparto que figura en la partitura: Carlota Michelet y Juan Muñoz, que cantaban en los Caños, y Vicente Sánchez Camas, que seguía esa temporada en el Príncipe.

\section{LOS INTERESES TEMÁTICOS DE JOAQUina COMELLA}

Resulta imposible, dentro de los límites de este trabajo, proceder a un estudio detenido de las cinco tonadillas presentadas aquí, dada la riqueza del material literario, musical y escénico conservado. Puesto que el objetivo fundamental de esta investigación es, como se ha señalado, acercarse a la figura literaria de Joaquina Comella y, a través de su obra, ahondar en el estudio del componente textual, literario de la tonadilla escénica, ese será el aspecto primordial de atención en las páginas siguientes, cuyo núcleo será el análisis y edición del libreto de La pasiega

46. Isidoro Máiquez, p. 594.

47. ANDioc, René y COUlon, Mireille. Cartelera teatral madrileña, I, p. 482.

48. Ambas compañías, la de la Cruz y la del Príncipe, actuaron esa temporada bajo la misma dirección, la de la Junta de Dirección de Teatros. 
y el hidalgo ${ }^{49}$. Con todo, una presentación general del conjunto de las tonadillas parece oportuna para aproximarse a los intereses temáticos de Joaquina Comella, algo que puede hacerse, aunque no se hayan conservado todos sus libretos, a través de la versión que nos proporcionan las partituras y los apuntes de teatro.

Las cinco tonadillas de Laserna a las que puso letra Joaquina Comella en 1800 apoyarían la revisión actual de la división del género establecida por Subiráso, según la cual pertenecen a la etapa de "Hipertrofia y decrepitud»" ${ }^{51}$. En todo caso, sí parece que corresponden a un momento en el que la tonadilla, en especial las tonadillas para interlocutores, ha ido perdiendo parte de su condición de retrato jocoso y pícaro de la realidad más inmediata en favor de una visión más aleccionadora y moral, que no estaba reñida con su carácter festivo ${ }^{52}$.

En efecto, la perspectiva moral sobre asuntos que interesaban a la sociedad española de 1800 es evidente en casi toda la producción de Joaquina Comella, no solo por la tendencia a un final de las obras que subraya la lectura moral, sino por la naturaleza de los temas tratados. El matrimonio es el más destacado. En su primera tonadilla conocida, La Anita, Comella trata del matrimonio desigual entre «el viejo y la niña", con un planteamiento que frustra las aspiraciones de don Canuto, viejo y achacoso pero rico, de casarse con su joven pupila, para hacer que esta, tras burlar a su tutor en compañía de su enamorado, logre unirse a él ${ }^{53}$.

Otros aspectos del matrimonio siguen interesando a Comella seis años después, cuando compone El marido pesado y El marido indiscreto, que abordan esta vez las dificultades de la vida conyugal. En la primera esa dificultad estriba en la incompatibilidad de caracteres entre una mujer de genio vivo y su marido, hombre poltrón y cachazudo. Como la convivencia resulta ya insoportable para Antonia, que no ve más salida que el divorcio, el maestro de música propone una argucia que haga reaccionar al marido y mude su sosería en viveza: darle celos. El medio puede ser reprobable, pero consigue evitar males mayores, como subraya la reflexión moralizante de la tonadilla: "Aunque siempre son malos / los fieros celos / producen muchas veces / buenos efectos ${ }^{54}$, antes de dar paso al Final donde se celebra la vuelta al sosiego de la vida conyugal.

49. Para un futuro trabajo queda el estudio y edición del otro libreto localizado, El marido indiscreto.

50. Véase Lolo, Begoña. "La tonadilla escénica, ese género maldito», p. 465; también LE GuIN, Elisabeth. "Hacia una revalorización de la tonadilla tardía». En Álvarez BARrienTos, Joaquín y LoLO, Begoña (eds.). Teatro y Música en España: los géneros breves en la segunda mitad del siglo XVIII. Madrid: Universidad Autónoma de Madrid-Consejo Superior de Investigaciones Científicas, 2008, pp. $183-195$.

51. SuBiRÁ, José. La tonadilla escénica. I, pp. 205-240.

52. Id., Ibid. II, pp. 88-89.

53. Véase el interesante análisis de Angulo EGEA, María. "Una tonadilla escénica. La Anita...», pp. 79-84.

54. Cito por el apunte teatral, f. 7r. La tentación de Antonia de «divorciarse» ("Desde hoy / voy [a] apartar cuarto, mesa / y cama, si es lo mejor», f. 2v) es muy reveladora de la actualidad del tema, 
En El marido indiscreto Joaquina Comella retoma la diferencia de edad entre los cónyuges para su reflexión sobre el matrimonio, esta vez pintando los peligros que puede acarrear una unión tan desigual entre un marido viejo y una mujer joven, petimetra por más señas. Se cuestiona aquí la fidelidad que tal mujer puede guardar a un esposo al que maltrata pero que bebe los vientos por ella, y se recurre de nuevo a un engaño, esta vez una apuesta entre el marido y su abogado, para salvar una vida conyugal de armonía más que dudosa en este caso: el abogado fingirá que seduce a Paca para probar al ingenuo marido la fidelidad de su consorte. El tono moral es en esta obra más cuestionable, a pesar de la letra de las boleras finales, que son un aviso a los esposos de que los celos son peligrosos, porque pueden traer resultas insospechadas, más si se apuesta sobre la fidelidad de las mujeres.

También el matrimonio está en el centro de la trama argumental de otras dos tonadillas. Muy interesante es el planteamiento que se hace en El novio y las dos hermanas, esta vez no por sus implicaciones sociológicas, sino histórico musicales. El novio llega a casa de las hermanas para decidir a cuál quiere como esposa, como le manda el tío de las jóvenes en una carta. Ambas cantan, y el novio ha de elegir entre la que canta boleras y la que canta arias italianas; ambas tienen gracejo y son hermosas, pero al final se decide por la primera. La tonadilla fue compuesta en 1800, solo unos meses después de que se prohibiera cantar o representar en los escenarios nacionales en otro idioma que no fuera el español y por actores no españoles. En este contexto, la obra de Joaquina Comella, aunque refleje la influencia italiana que, tanto en lo musical como en el texto, manifiesta la tonadilla en estos años ${ }^{55}$, no deja de ser una exaltación de la música española, con la elección final de su protagonista.

La duda ante el matrimonio asalta también al protagonista de La pasiega y el bidalgo, al descubrir que la mujer con la que va a casarse amén de ser beata tiene en casa a un niño de sospechoso parecido físico con ella; la pasiega que cuida a la criatura intenta sacar beneficio del aprieto en que se encuentra el ama, pero su engaño es descubierto y el matrimonio de la beata y el hidalgo se celebra con gran contento por ambas partes: ella porque el hidalgo es un hombre apuesto y rico del que queda prendada, y don Venancio porque la beatería de doña Petra, acostumbrada a mortificaciones y sacrificios, es al cabo una buena disposición para sobrellevar las penas del matrimonio.

que aparece planteado en estos mismos términos -los que contemplaba la legislación vigente sobre los conflictos conyugales- en comedias de estos años, como El matrimonio por razón de estado o La razón todo lo vence, del padre de Joaquina, Luciano Comella. Véase ANGUlo EgEA, María. Luciano Francisco Comella (1751-1812). Otra cara del teatro de la Ilustración, pp. 152-165, y GARCÍA GARROSA, María Jesús. "La escuela del matrimonio: los conflictos conyugales en el teatro español de finales del siglo XVIII». Bulletin of Hispanic Studies, 2015, 92.4, pp. 367-383.

55. Subirá, José. La tonadilla escénica. II, pp. 394-405. 
Y aunque también se resuelva con una boda, El majo y los dos hermanos se aparta de estos ambientes e intereses burgueses para enlazar con las raíces más costumbristas de la tonadilla. En una fonda coinciden dos hermanos italianos y un majo; la hermana está encandilada por el majo, y a él no le disgustan los ojos hechiceros de la italiana; en medio, el hermano, que recela del majo y de sus intenciones. Sus impedimentos nada valen ante las artes de los enamorados, que se van a celebrar su boda con la italiana reconvertida en maja. Sin llegar a ser un ejemplo de la tonadilla como «reflejo de la realidad barriobajera de finales del setecientos ${ }^{56}$, esta obra tiene un marcado carácter popular, a través del personaje del majo, que se manifiesta en sus rasgos lingüísticos ("petar", "prenda", "gembra", "aflejía") y otros elementos distintivos: una navaja que acaba de comprarse y esgrime ante el italiano, la guitarra, su gesto de picar cigarro, etc. El majismo, visto en las tonadillas o en otras formas de teatro breve como una reafirmación de lo popular ante las modas extranjeras ${ }^{57}$, tenía también la ventaja de dar variedad musical a la pieza y ofrecer al público diversidad de números y estilos; en El majo y los dos bermanos la joven italiana canta arias en esa lengua, acompañada del violín, y el majo pide la guitarra para cantar unas boleras. Y la italiana, la extranjera, acaba adoptando el traje y hasta el lenguaje castizo de una maja ${ }^{58}$.

Esta presentación muestra en primer lugar la variedad de registros en la producción de una autora que pasa de los asuntos y tonos más populares a los argumentos metamusicales sin renunciar a una temática de corte más social. En este sentido, una obra como la de Joaquina Comella puede servir para revisar, o cuando menos matizar, algunos de los tópicos que de manera casi generalizada se han repetido sobre las tonadillas. Aunque el público no esperara de estas piezas breves «una riqueza ideológica» que los autores no iban a darle ${ }^{59}$, estos no siempre y no solo escribieron piezas de circunstancias, sin más pretensiones que las de dar noticia jocosa de la actualidad y divertir al auditorio con el ingenio y la chispa de unos textos que la música y los cantantes realzarían. En el caso de las obras de Joaquina Comella su carácter de tonadillas costumbristas no está reñido con el interés que manifiesta la autora por ciertos temas y por un enfoque en el que el humor y los recursos cómicos refuerzan una postura moral. Porque son tonadillas costumbristas que llevan a la escena la realidad más inmediata, Joaquina Comella aborda en algunas de sus obras asuntos nada banales de esa realidad de la España de 1800, como los problemas conyugales derivados en buena medida de unos usos sociales que propiciaban matrimonios desastrados. No era, ciertamente,

56. Real Ramos, César y AlCalde Cuevas, Luis. "La tonadilla: un capítulo en la historia del espectáculo del siglo XVIII». En KLEINERTZ, Rainer (ed.). Teatro y música en España (siglo XVIII). Kassel: Reichenberger, 1996, p. 137.

57. SuBIRÁ, José. La tonadilla escénica. II, pp. 96-98.

58. La partitura indica incluso que aparece "Con un rejón en la mano" al salir del cuarto en el que se ha vestido de maja.

59. HutrTas, Eduardo. "La tonadilla escénica», p. 57. 
educar al público la función de estas tonadillas, pero la risa y el disfrute durante la representación podía dar paso a la reflexión al final del espectáculo.

En todo caso, a juzgar por los títulos ahora rescatados, parece que a Joaquina Comella le interesaban más los ambientes y temas burgueses que la vertiente más popular de la tonadilla escénica, algo que enlaza esta producción de su época de madurez con la obra que compuso en sus inicios como libretista, La Anita. Al mismo tiempo, su abanico temático muestra a una escritora que conoce bien las tendencias argumentales del momento en el género que practica y la situación más actual de la escena lírica en la España del cambio de siglo.

\section{El ARTE literario DE JOAQUina COMELla: LA PASIEGA Y EL HIDALGO}

Se ha insistido ya a lo largo de este trabajo en el carácter efímero de la tonadilla escénica, en su inmediatez, en la premura con que eran compuestas las obras, lo que redunda en el carácter casi oral de las mismas, esto es, en un proceso en el que la composición, la transmisión y la recepción se hacen de manera casi simultánea. Es desde esta concepción de espectáculo parateatral desde la que abordan su estudio de la tonadilla Real Ramos y Alcalde Cuevas, quienes subrayan la naturaleza popular de este género que cobra vida en su "performance", en su realizarse en el escenario, con la improvisación de los cantantes y la interacción con el público constituidos en factores tan relevantes como el libreto o la música ${ }^{60}$.

De esta consideración se sigue de manera casi natural la pobre valoración literaria de las tonadillas, en una generalización que también sería bueno matizar en una producción tan extensa y tan variada. Que el libreto solo adquiera sentido al ser puesto en música y subido a un escenario no anula el valor en sí mismo del texto literario, que puede analizarse desde su condición de texto dramático dotado de estructura, personajes, estilo, etc., sobre todo en las modalidades más complejas de tonadilla, las generales o para interlocutores.

Prueba de ello es la clasificación y definición que se hace de ellas en dos obras de teoría y preceptiva literaria muy conocidas por los musicólogos: "Origen y progresos de las tonadillas que se cantan en los Coliseos de esta Corte», publicado en el Memorial literario en 1787, y Principios de Retórica y Poética (1805), de Francisco Sánchez Barbero. El primer texto incluye las tonadillas a solo en la poesía lírica y las de interlocutores en la poesía dramática. En el primer modo «se imitan las costumbres; en este las acciones y costumbres, formando una pieza pequeña dramático-música con su introducción, fábula, episodio y solución, a que suele agregarse un final de Seguidillas, Caballo, Tirana, etc.» ${ }^{61}$. Sánchez Barbero también incluye las tonadillas dentro de la poesía dramática. Las unipersonales,

60. "La tonadilla: un capítulo en la historia...», pp. 131-132. Véase también en este sentido HuERTAS, Eduardo. "La tonadilla escénica», pp. 56-59.

61. Memorial literario, tomo XV, septiembre 1787 , pp. 173-174. 
añade, "se cantan enteramente: su objeto por lo regular es el ridículo", y las de interlocutores, "que se componen de cantado y representado, son unas operetas muy cortas, y comprenden el género serio, o el jocoso, o el pastoril. Las reglas de todos estos poemitas [musicales] son iguales a las de los grandes; en ellos deben brillar las imágenes, los cuadros y los sentimientos ${ }^{62}$.

Estamos ante textos de preceptiva, sin duda bastante alejados de la práctica escénica más generalizada entre los compositores de tonadillas; sin embargo, hay que subrayar la insistencia de ambos en que, en su parte literaria, es decir, en los libretos, estas obritas tienen una estructura dramática y unas reglas de composición, y, por tanto, los poetas dramáticos deben esforzarse en buscar unos recursos que satisfagan esas exigencias literarias, que no están reñidas con el afán de agradar al auditorio.

Este parece ser el caso de Joaquina Comella, una autora que muestra cuidado en su labor creativa y conocimiento de los resortes dramáticos del género que practica. Los dos libretos ahora recuperados, la obra suya, previa a las intervenciones del músico y el «autor» de la compañía, permiten acercarse a esos elementos propiamente literarios, como vamos a ver con el de La pasiega y el hidalgo.

El argumento de La pasiega y el hidalgo puede resumirse así: el hidalgo don Venancio ha llegado a la Corte para concluir la boda con doña Petra, a la que no conoce, y que parece ser una beata por los libros de devoción que están en su sala. Doña Petra está en la iglesia, y le recibe la pasiega que cuida de un niño que levanta enseguida los recelos del hidalgo. La pasiega, por su parte, ve la ocasión de salir de viuda quitándole el novio a su ama; para ello le engañará haciéndole creer que el crío es hijo de la beata. El hidalgo cae en esa simple trampa, al ver el parecido del niño con doña Petra y al hacer preguntas sobre su origen que no obtienen respuestas convincentes ni de la novia ni de la pasiega. La llegada providencial de la carta de la hermana diciendo que todo se ha solucionado con la familia de su esposo y que pronto pasará a recoger a su hijo resuelve las dudas del novio, frustra las aspiraciones de la pasiega, y da paso al final feliz, con la boda entre el hidalgo y la beata y la moraleja final: la pasiega reconoce que «mal me ha salido el engaño» (v. 197), don Venancio sabe que no merece el rápido perdón de doña Petra porque ha dudado de ella, y los tres cantan que se equivoca el que juzga rápidamente por las apariencias, condenando «al infame detractor» (v. 202) y alabando tres virtudes, «la inocencia / la prudencia y el candor» (vv. 203-204) ${ }^{63}$.

Puede verse enseguida que La pasiega y el hidalgo no está constituida por una mera sucesión de números musicales sin conexión, ni presenta una historia sin mucho sentido ni ligazón argumental. Hay en esta pieza, como señalaba la

62. SÁnchez [BARBero], Francisco. Principios de Retórica y Poética. Madrid: Imprenta de la Administración del Real Arbitrio de Beneficencia, 1805, p. 256

63. Citaré los versos por la edición del libreto de La pasiega y el hidalgo que se incluye al final de este trabajo. 
breve preceptiva divulgada en 1787 en el Memorial literario, «introducción, fábula [esto es, argumento], episodio y solución", vale decir que hay una estructura dramática reconocible, que enseguida analizaré, y hay, por tanto, una voluntad literaria que se manifiesta también en el plano estilístico y poético.

El argumento de esta tonadilla y el motivo central (la confusión sobre la paternidad de un niño por su parecido físico con un familiar que se ha hecho cargo de él) no son una novedad, pero sabemos que no hay que buscar originalidad en un género estereotipado en sus formas y contenidos como este. Hay una tonadilla a tres de Pablo del Moral, La pasiega, en la que un marido paga a una pasiega para que críe al niño de un primo suyo; la pasiega cree que la criatura es suya, porque "los ojos, el pelo / las narices, y la boca, / son de usted»; puede imaginarse la reacción de la mujer, que ha escuchado oculta esta conversación, pero el equívoco se resuelve pronto, la esposa perdona y la tonadilla termina con un convencional "De nuevo la calma / volvamos a gozar" ${ }^{64}$. Bien pudo conocer Joaquina Comella esta tonadilla e inspirarse en ella, pero a pesar de ciertas semejanzas estamos ante obras muy diferentes.

El tema de La pasiega y el hidalgo no es la boda o la beatería de doña Petra, sino el engaño ${ }^{65}$, el que urde la pasiega para quitarle el novio a su ama, del que previene la moraleja final. Y es el engaño el motivo que articula la trama y la estructura tanto dramática como musical de la tonadilla ${ }^{66}$.

El núcleo de la pieza es el trío de los versos 142-170, en el que se manifiesta el engaño de la pasiega con las tres posturas: el honor de la beata mancillado por la insinuación de don Venancio de que el niño es suyo, las sospechas crecientes de este ante el parecido físico y su negativa a casarse con semejante «dote», y la actitud de la pasiega, que no quiere secundar a su ama para descargarla de sospechas con respuestas que aumentan su aparente culpabilidad y el rechazo de don Venancio. ¿Cómo se llega a este punto central y cómo se resuelve el conflicto planteado?

La situación se presenta en los versos 1-30: la llegada de don Venancio a la Corte para casarse (Introducción, vv. 1-10), el descubrimiento de que la novia es una beata (Parola, vv. 11-18) y las quejas de la pasiega sobre su condición (Coplas $1 .^{\mathrm{a}}$ y $2 .^{\mathrm{a}}$, vv. 19-22 y 27-30). La tonadilla entra ya en el nudo de la acción dramática: el dúo y el diálogo hablado siguientes (vv. 31-52) sirven para plantear los intereses

64. Cito por el libreto, conservado en la Biblioteca Histórica Municipal de Madrid (Tea, 222149), y que tiene fecha de 1798.

65. Como se ve en el título, en el que figuran los personajes que sustentan el tema: la engañadora y la víctima del engaño.

66. El engaño es también el eje dramático de La Anita, aunque con diferente propósito y resultado (frustrar el proyecto del tutor de casarse con su pupila y lograr la unión deseada por los jóvenes amantes Anita y Juan). Y al engaño recurre Joaquina Comella en las dos piezas de tema matrimonial, El marido indiscreto y El marido pesado, esta vez con una intención más cuestionable desde el punto de vista moral, probar al marido o lograr un cambio en su conducta. 
y estrategias de cada uno: el novio quiere sonsacar a la pasiega sobre la beatería de la novia, y a la criada se le ocurre quitárselo al ama.

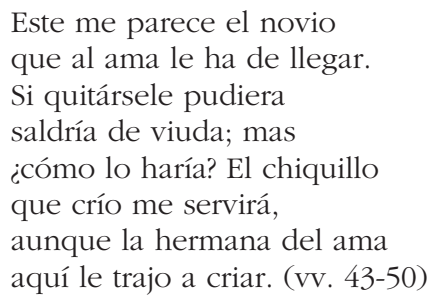

Ocho versos le sirven a la autora para presentar el tema del engaño, sus motivos y sus medios; es un ejemplo elocuente de cómo lograr la máxima eficacia dramática con pocos elementos en un género breve ${ }^{67}$.

La ausencia de la beata ${ }^{68}$ y la excusa argumental de que la pasiega entre y salga de escena para colgar la ropa, los pañales del niño, o para calmar los llantos de este, permiten que don Venancio muestre su inquietud por la existencia de un niño de pecho y un ama de cría en la casa de la que va a ser su mujer (vv. 5964 y 71-72), y para que la pasiega dé nuevos toques a la figura de aquella, una buena cristiana muy dada a los rezos y devociones (vv. 54-56). La acción avanza en las partes habladas de la pasiega, mientras las dudas del novio se expresan en números musicales repetidos.

Doña Petra aparece al fin, y el libreto reserva una parte importante de la tonadilla al descubrimiento mutuo de los futuros esposos (dúo en los vv. 87-101): a ella le van cautivando los "ojuelos picaruelos" de este mozo apuesto y con haberes, y a él le parece "muy juiciosa / por su traje, por su aliño» (vv. 91-92). Es la parte más cómica de la obra, con una beata poco acostumbrada a la vista de los hombres presa de vapores y sofocos, indecisa sobre cómo abrazar a su prometido, y que permite también dar unos toques de picardía al encuentro.

\begin{tabular}{|c|c|}
\hline HidALGO. & $\begin{array}{l}\text { ¡Si este espárrago enlutado } \\
\text { será la novia! ¿Qué es esto? } \\
\text { Anímese. }\end{array}$ \\
\hline BEATA. & $\begin{array}{l}\text { Con su vista } \\
\text { parece que hallo consuelo. } \\
\text { Pero sois hombre. }\end{array}$ \\
\hline $\begin{array}{l}\text { HidALGO. } \\
\text { BEATA. }\end{array}$ & Así dicen \\
\hline
\end{tabular}

67. Como puede verse en la edición de la tonadilla, el músico ha reemplazado estos versos por otros menos ricos en información.

68. Obsérvese que este personaje tarda en aparecer, un recurso muy eficaz para caracterizarla indirectamente, antes de que el espectador la vea, y para permitir en su ausencia el desarrollo de la intriga en torno al engaño. 


$\begin{array}{ll}\text { Hidalgo. } & \text { Yo así lo creo. } \\ \text { BEATA. } & \text { Pues de lejos me asustasteis. } \\ \text { HidALGO. } & \text { ¿Y de cerca? } \\ \text { BEATA. } & \text { Vade retro. }(\text { vv. } 77-84)^{69}\end{array}$

Pero la acción avanza rápidamente: las dudas de don Venancio («Entre el chiquillo y sus ojos, / Venancio, ¿qué es lo que harás?», vv. 110-111) se resuelven ante la evidencia cuando ve al niño: «Estas cejas son sus cejas, / estos ojos son sus ojos, / estos labios son sus labios. / Yo no sufro estos agravios / ni me quiero ya casar" (vv. 121-124). El trío central de los versos 142-170 y la Parola que precede (vv. 128-141) suponen, como he apuntado, el clímax dramático, con el equívoco sobre la identidad del niño favorecido por el silencio pertinaz de la beata al respecto, y con versos que definen de forma eficaz la postura de cada personaje: «Bien va saliendo el enredo", insiste la pasiega, «Honor mío, ¿qué te has hecho?», se lamenta la beata, mientras el hidalgo canta, con variaciones, «qué petardo te pegaban!».

Y la solución ha de llegar con la misma prontitud: una carta que, al revelar la verdadera paternidad del niño, pone de manifiesto el engaño de la pasiega y resuelve las dudas del hidalgo sobre su matrimonio. El tema ha quedado cerrado en una estructura dramática sencilla, pero coherente y bien organizada. Solo resta el cierre, que en esta etapa en la que la tonadilla ha perdido ya el remate tradicional con Seguidillas o Boleras, adopta la forma de Fina ${ }^{0}$, una pieza musical de perfecta conexión argumental con el cuerpo de la tonadilla: es celebrativa ( Vamos, vamos, beata mía, / nuestro enlace a celebrar», vv. 193-194), pero sobre todo moral, pues se condena en el terceto final tanto el engaño como el juicio precipitado basado en las apariencias.

Joaquina Comella, como vemos, es una escritora que revela su manejo de las estructuras dramáticas y musicales de la tonadilla, y que se muestra igualmente hábil para aprovechar al máximo los recursos literarios al servicio del argumento en un género tan breve. Así, el texto escrito es de tal precisión en ciertos momentos que suple las acotaciones, escasas en el libreto. La partitura de Laserna es profusa en estas indicaciones escénicas, pero en ciertos casos son innecesarias, porque toda la información para la representación está en los propios versos, tanto en lo que se refiere a la acción como a la caracterización de personajes. Valga el ejemplo citado más arriba (vv. 77-84), con la primera aparición de doña Petra en escena: los versos nos dicen que la beata es delgada y va vestida de negro, y que es mujer poco dada al trato con hombres, pues se desmaya del susto al ver a uno en su casa.

69. Es fácil imaginar el tono provocador que los actores darían a estas réplicas; pero parece que estos versos no llegaron a oírse en el teatro, porque han sido sustituidos por otros en la partitura y el apunte. Véase la nota 97 de nuestra edición.

70. Subirá, José. La tonadilla escénica. II, pp. 272-282. 
El buen hacer de Joaquina Comella también es visible en la creación de personajes. Sabemos que la tonadilla -menos por su brevedad que por su carácter estereotipado- no permite grandes despliegues en su configuración, ni un mínimo desarrollo psicológico ${ }^{71}$. Muchos de ellos pertenecen a la tradición entremesil, o a la comedia de figurón, que ya proporcionan al autor de los libretos los rasgos esenciales del personaje en cuestión ${ }^{72}$. Sin esperar, pues, una hondura dramática poco propia del género, destaca sobre todo en La pasiega y el hidalgo, como en el resto de la producción de Comella, la capacidad para crear tipos bien resueltos con unas pocas pinceladas. Ya hemos visto cómo pinta a doña Petra, a una beata, no solo por sus acciones, sus palabras o su aspecto, sino de forma indirecta, por los libros que tiene en su sala, o la eficaz descripción que hace de ella la pasiega ${ }^{73}$.

Más sutil es quizá el personaje de la pasiega. Viene caracterizada en primer lugar por su lenguaje, aunque no son rasgos propiamente dialectales los que lo definen, sino registros bajos o vulgares (como el cierre de las vocales finales: "ellu», "tuvierun", "nun sé») con los que Comella quiere reproducir un habla que "Suena» a venido del norte de España. Ella es la protagonista de la tonadilla, quien pauta la intriga dramática, porque maneja la información (de quién es el niño que cría) y puede engañar en su propio beneficio; es, pues, astuta, y guía su conducta un claro afán de medro social: salir de viuda casándose con ese buen partido que se le presenta a la beata. El retrato lo completa el elemento de crítica social que se percibe en sus dos primeras coplas, en las que critica a su ama por estar más pendiente de sus devociones que del cuidado de su sobrino (vv. 27-30), y, por extensión, a todas las mujeres que abandonan la crianza de sus hijos dejando esa responsabilidad a las amas de cría (vv. 19-22) ${ }^{74}$.

El motivo que da inicio a la acción en esta tonadilla es una boda, por lo que de don Venancio interesa sobre todo su condición de novio y su concepción del matrimonio. La pasiega al verlo lo describe como «un fantasmón», es decir, como un hombre presuntuoso, lo que cuadra bien a un hidalgo provinciano poco dispuesto a dejarse engañar. Su carta de presentación de quien ha decidido su casamiento con doña Petra (¿el padre de esta, el hermano, su tutor?) lo presenta de manera eficaz con tres rasgos: "Es bien hecho, bien fornido / y está lleno de caudal» (vv. 89-90). En los ambientes burgueses que atraen con preferencia el

71. Véase Subirá, José. La tonadilla escénica. II, pp. 95-100, y Real Ramos, César y AlCALdE Cuevas, Luis. "La tonadilla: un capítulo en la historia...", p. 141.

72. Véase, en este sentido, lo que escribe Angulo EgEA, María. "Una tonadilla escénica. La Anita...", pp. 81-82, sobre el personaje de don Canuto.

73. Parte de los rasgos de este personaje se ha perdido o atenuado en la puesta en música de este libreto, como se explica en las notas a la edición de la tonadilla.

74. Es una crítica muy común a finales del siglo XVIII, cuando una abundante literatura higienista reivindicaba la lactancia materna y el cuidado personal de las madres para con la prole. Véase Bolufer, Mónica. Mujeres e Ilustración. La construcción de la feminidad en la España del siglo XVIII. Valencia: Institució Alfons el Magnànim, 1998, pp. 227-248. 
interés dramático de Joaquina Comella, el dinero es la base de la unión matrimonial, aunque la mutua complacencia de los contrayentes es evidente en este caso. Y si una beata enlutada y seguramente no muy joven echa para atrás a este novio apuesto, no deja de reconocer las ventajas de una esposa hecha a los sacrificios y las mortificaciones: "cilicios y disciplinas, / esto es lo que quiero yo, / que así llevará la cruz / del matrimonio por Dios» (vv. 15-18).

Queda un elemento por analizar en la técnica literaria de esta tonadilla: la versificación. La existencia del libreto de La pasiega y el hidalgo, desprovisto de las repeticiones de versos o palabras -indicativas de las repeticiones en el cantado- que aparecen en los apuntamientos teatrales o en las partituras, permite el reconocimiento de la estructura métrica de esta obra. En este terreno también, la lectura del texto salido de la pluma de Joaquina Comella muestra el interés de la autora por que sus libretos sean correctos desde el punto de vista métrico, aunque supiera que la música podía ocultar las deficiencias rítmicas, de medida o de rima. Una vez más, la actitud creativa de Joaquina Comella, su sentido estético, parece desmentir la consideración generalizadora de que los anónimos libretistas no se esmeraban en unos textos al servicio de la música, que con toda probabilidad serían alterados por los cantantes o el propio compositor, y cuyos posibles defectos corregiría la música ${ }^{75}$.

La tonadilla escénica se caracteriza por la variedad de metros y estrofas empleadas, sin una estructura poética fijada. La pasiega y el hidalgo refleja esa variedad, con una preferencia por los versos de arte menor, tanto de rima asonante como consonante. Las partes habladas son en romance octosílabo, con diferentes rimas, y también el trío de los versos 142-170. Hay algunas formas estróficas: seguidillas simples de versos de siete y cinco sílabas (las dos coplas de la pasiega, vv. 19-22 y 27-30), cuarteta hexasilábica (la copla de la beata, vv. 73-76), sextillas de versos hexasílabos (copla 1. ${ }^{\mathrm{a}}$ del hidalgo, vv. 59-64), u octosílabos (Final, vv. 193-204), octavilla de versos octosílabos (inicio del dúo del hidalgo y la beata, vv. 87-94), cuarteta octosilábica de rima abbc (trío de los vv. 175-186). El resto de la tonadilla presenta diversas combinaciones, no estróficas, de versos de diferente medida y rima, o incluso versos sueltos, como al inicio de la Introducción.

\section{FINAL}

Llegados al final del análisis, no quedan dudas sobre la valoración literaria de esta obra. El libreto de La pasiega y el hidalgo muestra que Joaquina Comella sabe desarrollar un argumento de manera coherente y eficaz, con una intriga que avanza y se resuelve, dotando la pieza de una estructura dramática interna; sabe crear personajes y utilizar los recursos cómicos del lenguaje o de las situaciones.

75. SubIRÁ, José. La tonadilla escénica. II, pp. 283-284. 
Es una valoración que corrobora la lectura del segundo libreto conservado, El marido indiscreto, y que se aprecia también en las tres tonadillas restantes a través de sus apuntamientos de teatro o las partituras.

Hay en Joaquina Comella una voluntad literaria incuestionable, y un trabajo de composición que muestra habilidad, ingenio, conocimiento de los resortes del género, capacidad de combinar los elementos tradicionales con una visión más novedosa. El primero en reconocer la valía de su obra fue Blas de Laserna. El que un músico como él, en pleno apogeo de su carrera como compositor, eligiera varios libretos de Joaquina muestra su confianza en la autora, en su capacidad para dar una estructura interesante a una tonadilla, de modo que él no tenía más que dar forma musical a ese material que ella había organizado literariamente, en un trabajo conjunto en el que la faceta creadora de uno necesariamente hubo de influir en la del otro. Se trasladaría así a la hija la misma confianza que el músico navarro depositó en el padre como libretista, y que tantos frutos daría en varios géneros $^{76}$. El descubrimiento de una producción elevada de Joaquina Comella, toda para Laserna, es prueba de una sintonía entre ambos que deja el campo abierto a nuevas investigaciones para ver si esa colaboración se extendió a otras tonadillas u otros géneros dramático-musicales.

La calidad literaria de los textos de Joaquina Comella nos permite en estas conclusiones enlazar con otras ideas planteadas al inicio de este trabajo. El saber que compuso siete libretos de tonadillas en 1800 confirma en primer lugar que no fue una escritora ocasional, autora de una única obra de muy temprana juventud surgida por casualidad, sino una autora con voluntad creadora, con intención de desarrollar una carrera en el mundo de las letras, en un terreno no muy frecuentado -que sepamos hasta ahora- por otras escritoras dieciochescas como es la tonadilla escénica. Esta producción del final de su carrera literaria pone de manifiesto que la autora conoce bien los gustos del público y las artes de su oficio, no menos que las claves del género que practica, algo que ya se apreciaba en su obra de juventud, La Anita, y con más motivo ahora, en su madurez, cuando podemos suponerle una experiencia dramática amplia que casi con toda certeza se desarrolló de manera continuada entre 1794 y 1800, año de su muerte.

El hecho tiene interés no solo para trazar un perfil más preciso de esta dramaturga, sino para el conjunto de la creación literaria femenina en el siglo XVIII español, pues se va documentando, con nuevos textos, una producción más abundante y una actividad literaria más regular entre nuestras escritoras. En este sentido, me parece importante subrayar la cercanía que muestra Joaquina Comella

76. «Comella contaba con este excelente compositor para sus piezas y Laserna confiaba en las indicaciones del dramaturgo a la hora de escribir su música", concluye ANGulo EgEA, María. "Luciano Francisco Comella (1751-1812), el melólogo y Doña Inés de Castrom. En Comella, Luciano Francisco y Laserna, Blas de. Doña Inés de Castro, escena trágico lírica. Ed. Angulo EgEA, María, Labrador LóPEZ DE Azcona, Germán y García Martínez, J. Daniel. Salamanca: GES XVIII-Ediciones Amnesia, 2005, p. 26. 
con las preocupaciones de otras escritoras de su generación; varias de sus obras manifiestan los mismos intereses por unos temas que afectan directamente a la situación de las mujeres, como ya se vio en La Anita, y que reflejan el estado de la sociedad española del cambio de siglo. Es un rasgo de su modernidad, con una producción que ejemplifica igualmente la evolución de la tonadilla escénica finisecular hacia temas burgueses y enfoques más morales.

Uno de los objetivos que ha guiado este trabajo ha sido poner en valor el componente literario de la tonadilla escénica a través de los nuevos libretos conocidos de Joaquina Comella. Es una autora, un caso en una producción muy amplia, variada e irregular, pero un caso al fin que permite ver el enriquecimiento que para el conocimiento de este género dramático-musical puede suponer el abordarlo, también, desde la perspectiva filológica. Ello propiciaría una valoración más matizada de estas piezas breves, calificadas pertinazmente como obras menores, rudimentarias e intrascendentes, compuestas sin esmero por autores de escasas dotes, textos, se diría, sacrificados a su consumo inmediato. Las generalizaciones que afectan a las tonadillas recaen en buena medida en considerarlas, en el aspecto textual, una labor creativa adocenada e impersonal; por ello, individualizarlas en lo posible, rescatando el nombre de los autores de los libretos, parece tarea esencial en el estudio de este género, como lo es reivindicar la calidad literaria de algunos de esos dramaturgos y de sus obras.

\section{APÉNDICES}

Se incluyen como apéndices de este trabajo la edición crítica del libreto de La pasiega y el hidalgo y la documentación relativa a las solicitudes de licencia de representación de siete tonadillas de Joaquina Comella y Blas de Laserna cursadas en 1800 .

En el primer caso reproduzco el texto que figura en el manuscrito del Archivo Histórico Diocesano de Madrid (Caja 9186) que contiene la Tonadilla á 3. La Pasiega y el Ydalgo. En su transcripción he normalizado la ortografía, la acentuación y la puntuación de acuerdo con los criterios actuales. Mantengo los rasgos lingüísticos de la pasiega ("ustéis», "tuvierun», "ellu»), porque constituyen un elemento definitorio del personaje, y regularizo las formas «Vmd.» / «usté» que se presentan de manera indiscriminada en el texto. Las notas léxicas remiten, salvo indicación contraria, al Diccionario de la Real Academia Española en su edición de 1791, la anterior más cercana a la fecha de composición de la obra. Para facilitar su lectura, sustituyo el nombre de los actores que figuran en el manuscrito por los personajes: (Mariano) Querol > Hidalgo; Joaquina (Arteaga) > Pasiega; Manuela (Correa) $>$ Beata.

Tengo en cuenta también en esta edición los documentos teatral y musical de la tonadilla. En nota indico las variantes más significativas que se registran respecto a la letra del libreto en el apunte de teatro (BHM, Tea 222-150) y en la 
partitura de Blas de Laserna (BHM, Mus 125-1); no anoto cambios del tipo "Esto es ya mucho apretar" > "Esto ya es mucho apretar", por considerarlos irrelevantes en la configuración de una u otra versión. Igualmente, señalo en los lugares oportunos las indicaciones musicales de tempo y compás de la partitura, que implican en algunos casos la corrección del libreto en cuanto a la división del texto en sus partes habladas o musicales.

He actualizado igualmente la ortografía, acentuación y puntuación de los documentos de censura, procedentes del Archivo Histórico Diocesano de Madrid (Caja 9187), en cuya transcripción he desarrollado las abreviaturas.

\section{APÉNDICE 1}

Tonadilla a 3

\section{La pasiega y el hidalgo}

[f 1r] Compañía del Sr. Navarro

\section{Introducción $n^{77}$}

HidALGO.

Ya en la Corte me encuentro, y en casa de la novia; solo falta casarnos para concluir la boda.

$5 \quad$ Mas nadie parece; ¿si la llamaré?...

Rezando a estas horas ${ }^{78}$ puede ser que esté. Pues es preciso esperarla, 10 de este modo esperaré. (Se sienta a leer libros)

\section{Parola}

El temporal y el eterno, El Kempis: ${ }^{79}$ buena elección ${ }^{80}$.

77. Allegro (2/4).

78. "Tal vez ocupada», en la partitura y en el apunte teatral. El cambio elimina el elemento religioso.

79. De la diferencia entre lo temporal, y eterno: crisol de desengaños (1640), de Juan Eusebio Nieremberg, y De la imitación de Cristo (siglo XV), de Tomás de Kempis, eran dos de los libros de devoción más difundidos y conocidos de la religiosidad moderna, con varias ediciones en el siglo XVIII.

80. Los versos 11-16 son sustituidos en la partitura y el apunte teatral por: «El año cristiano, bueno / pero aún falta lo mejor: / dos novenas, una estampa, / esta novia quiero yom. Año cristiano, o Ejercicios de piedad para todos los días del año (12 vols., 1753-1773), traducción del padre José Francisco de Isla de la obra francesa del jesuita Jean Croisset (1712), fue uno de los libros de devoción más 
¿Si será beata la novia?...

Pero aún falta lo mejor: esto es lo que quiero yo, que así llevará la cruz del matrimonio por Dios.

$$
\text { 1. }{ }^{a}[\text { Copla }]^{81}
$$

PASIEGA.

La pasiega que cría

(Canta dentro)

hijos ajenos

se mete en los cuidados

que otros tuvierun.

\section{Hablado}

HidALGO,

La que está cantando adentro

no estudiará para monja.

25 ¿Si será la novia?... Ca...

Pero aquí viene una moza.

$$
\text { 2. }{ }^{a}[\text { Copla }]
$$

Sale Pasiega.

[f $2 \mathrm{r}$ ]

Entre tanto que el ama

revuelve libros,

más valiera cuidara

30 mejor el niño ${ }^{82}$.

\section{Coleta}

HidALGO.

PASIEGA.

Hidalgo,

PASIEGA.

Hidalgo.

PASIEGA.

Yo no entiendo lo que dice ${ }^{83}$. ¿Quién es este fantasmón? ${ }^{84}$

¿Adónde vas tan corriendo?

A tender esto al balcón.

HidALGO.

Espera un poco.

¿Qué quiere vmd.?

Deja el barreño,

te lo diré.

famosos del siglo XVIII. La obra tuvo otra traducción, en seis tomos, con la parte correspondiente a los ejercicios devotos de los domingos y fiestas movibles del año, por Joaquín Castellot en 1773, con tres ediciones más antes de la fecha de composición de esta tonadilla. Es por ello muy significativa esta actualización del manual de devoción que hace Laserna en la partitura con respecto a los libros que Joaquina Comella menciona en el libreto.

81. Allegro poco (6/8).

82. "de su sobrino", dicen la partitura y el apunte. El cambio es importante, porque, cuando unos versos más adelante la pasiega planee su engaño al hidalgo, los espectadores ya sabrán que el niño es sobrino de la beata.

83. "Esta creo que es pasiega", en la partitura y el apunte.

84. Fantasmón: «Hombre presuntuoso». 
De la pasiega

me informaré.

PASIEGA.

Si me pregunta, ¿qué le diré?

\section{$[\text { Parola }]^{85}$}

Este me parece el novio

que al ama le ha de llegar.

Si quitársele pudiera saldría de viuda; mas ¿Cómo lo haría? El chiquillo que crío me servirá, aunque la hermana del ama aquí le trajo a criar ${ }^{86}$

Hidalgo. Muchacha, ¿qué estás

PASIEGA. A la postre se verá ${ }^{87}$.

HidAlgo.

PASIEGA. Mas ¿đónde está doña Petra? ${ }^{88}$

HidALGO.

PASIEGA.

HidALGO. [f $3 r$ ]
Se ha marchado a confesar ${ }^{89}$.

55 Dicen que es buena cristiana.

Nunca deja de rezar.

Mas voy a tender la ropa, que el sol se me va a escapar.

$$
\text { 1. }{ }^{a}[\text { Copla }]^{90}
$$

\section{Esto necesita}

mucha reflexión:

pasiega, cilicios,

niño y confesión ${ }^{91}$, con el turuleque ${ }^{22}$ viene mal el don.

85. Esta indicación proviene de la partitura y el apunte, pues no aparece en el libreto; este marca el inicio de la Parola en el verso 53.

86. Los versos 45-50 son sustituidos en la partitura y el apunte por éstos, menos sutiles: «Con su sobrino resuelvo / hacerle un rato rabiar / para ver si de este modo / me le puedo yo apropiar».

87. La partitura y el apunte añaden dos versos: «No hay remedio: con el novio / la voy a poner en mals.

88. En este verso indica el libreto una Parola que elimino, pues, como se ha señalado, la parte hablada ha comenzado en el verso 43.

89. «Se ha marchado a pasear", en la partitura y el apunte. Como en el v. 7 , este cambio muestra la voluntad del músico de atenuar el elemento religioso en el comportamiento de la beata.

90. Allegretto $(6 / 8)$. apunte.

91. "Esto necesita / consideración: / chiquillo, pasiega, / mucha devoción», en la partitura y el

92. Turuleque: «Voz de mera invención, que se usa en la frase jocosa que dice, no dice el don con el turuleque, no guarda consecuencia, no viene uno con otrom. Diccionario castellano, de Esteban Terreros y Pando, vol. III, 1788. 


\section{Parola}

Sale PASIEGA.

HidALGO.

PASIEGA.

HidALGO.

Sale BEATA.

[f 3v]

75

HidALGO.

BEATA.

HidALGO.

BEATA.

HIDALGO.

BEATA.

HidALgO.

BEATA.

HIDALGO
65 Ya he tendido los pañales.

Mas ¿¿de qué sirves tú aquí?

¿No lo ve usteis? De pasiega.

Pero ya empieza a gruñir

el muchacho; luego vuelvo.

(Vase)

¡Que esto me suceda a mí!

\section{$[\text { Música }]^{93}$}

Esto necesita

mucha reflexión, etc.

\section{Música suelta ${ }^{94}$}

Pues ya he consultado con mi consultor.

Pero aquí hay un hombre, ¡válgame el Señor!95

\section{Parola}

¡Si este espárrago ${ }^{96}$ enlutado será la novia!97 ¿Qué es esto? Anímese.

Con su vista parece que hallo consuelo.

Pero sois hombre.

Así dicen.

¿De veras?

Yo así lo creo.

Pues de lejos me asustasteis.

¿Y de cerca?

\section{Vade retro.} Piradlos por este pliego.

93. Esta indicación no figura en el libreto, y proviene de la partitura: Allegretto (6/8).

94. La partitura prescinde de esta indicación, pero marca el cambio de tempo y de compás: Allegro poco (4/4).

95. «Jesús, qué vapor!», en la partitura y el apunte.

96. Por delgada, fina.

97. En la partitura y el apunte esta Parola aparece como sigue: «HIDALGO: ¡Si este espárrago enlutado / será la novia! / ¿Qué es esto? ¿Qué tiene usted? / BEATA: Que del susto me dio un soponcio. / Hidalgo: Lo siento. / Beata: ¿Pero usted quién es? / Hidalgo: El novio, / miradlo por este pliego». La variante elimina la picardía de las réplicas escritas por Joaquina Comella.

98. Corrijo el «Mirarlo» del manuscrito. 


\section{$\left[\right.$ Música ${ }^{99}$}

BEATA.

[f $4 \mathrm{r}$ ]

90

HIDALGO.

LOS 2 .

BEATA.

HIDALGO.

[f 4v] BEATA.

HIDALGO.

[BEATA.]

[HidALGO.]

BEATA.

HIDALGO.

BEATA
«El dador de esta es el novio

que te tengo prevenido.

Es bien hecho, bien fornido

y está lleno de caudal».

Me parece muy juiciosa

por su traje, por su aliño;

mas los pañales del niño

me comienzan a oler mall ${ }^{100}$.

95 De pies a cabeza

mirándome está.

De mi aire de taco ${ }^{101}$

prendando ${ }^{102}$ se va.

Yo me llego poco a poco.

100 Ya se acerca, iqué sofoco!

Yo no sé lo que me da.

\section{Parola}

¿Me abraza vmd. o le abrazo?

Lo mejor será a la par.

Mas ¿đónde vas, don Venancio?

105 ¿Qué tiene vmd. que pensar?

Vamos, vamos, hijo mío.

¿Hijo tuyo? Lo será.

Tú solamente gachón ${ }^{103}$.

Esto es ya mucho apretar.

110 Entre el chiquillo y sus ojos,

Venancio, ¿qué es lo que harás?

Ya lo he resuelto; esto es hecho.

¿Dónde vas?

Ya lo verás.

$$
[\text { Música }]^{104}
$$

Sus ojuelos picaruelos

115 me han herido el corazón.

99. No aparece esta indicación en el libreto (que, en este caso como en otros posteriores, marca el cambio a música con el signo =), pero sí en la partitura: Allegro (4/4).

100. La partitura y el apunte han cambiado este verso por "me dan mucho que pensar", con lo que se elimina el doble sentido del verso original y su efecto cómico.

101. Aire de taco: «El movimiento garboso y vivo. Dícese por lo común de las mugeres». DRAE. 1803.

102. Corrijo el "prendado» del manuscrito del libreto conforme al "prendando» del apunte, más apropiado.

103. Gachón: «El niño que se cría con mucho regalo, y se le da gusto en todo».

104. Esta indicación no figura en el libreto, y proviene de la partitura: Allegro assai (2/4). 
Sale PASIEGA.

Beata y PASIEga.

HiDALGO.

[f $5 \mathrm{r}$ ]

PASIEga y BeATA.

HIDALGO

BEATA.

[HIDALGO.]

BEATA.

PASIEGA.

HidALGO.

BEATA.

[f 5v] HidALGO.

PASIEGA.

BEATA.

[PASIEGA.]

BEATA.
Suelta, suelta ese muchacho.

Voy a ver de este gazpacho

si averiguo la razón.

Yo no sé qué está pensando con tan grande reflexión.

Estas cejas son sus cejas,

estos ojos son sus ojos, estos labios son sus labios.

Yo no sufro estos agravios

125 ni me quiero ya casar.

No afurquiñe ${ }^{105} /$ estropee vmd. al muchacho que lo puede reventar.

\section{Parola}

A la paz de Dios, señora.

¿Por qué os vais?

Porque no quiero

130 que lleve en dote mi novia esta clase de embelecos ${ }^{106}$.

¡Qué lengua tan criminal!

El muchacho es un misterio, un $\operatorname{arcano}^{107}$ incomprensible.

135 Bien va saliendo el enredo ${ }^{108}$

¿De quién es?

Debo callarlo

¿Y tú lo sabes?

Soy cero.

Sálvame, sincérame, (A la pasiega)

que bien sabes que es ajeno ${ }^{109}$.

140 Ellu de alguno ha de ser.

Honor mío, ¿qué te has hecho? ${ }^{\text {?10 }}$

$[\text { Música }]^{111}$

¿Te he entregado yo este niño?

Respóndeme sin tardanza.

105. Afurquiñar es voz gallega: "Aguijar, matar".

106. Embeleco: "Embuste, engaño".

107. Arcano: "Lo mismo que secreto muy reservado, y de importancia». DRAE. 1803.

108. Este verso se omite tanto en la partitura como en el apunte de teatro, que en cambio añaden uno más a la anterior intervención de la Beata: "que aclararé con el tiempo".

109. Los versos 136-138 se presentan en el apunte y la partitura con esta variante: "HIDALGO: ¿De quién es? / Beata: Ya lo sabrá. / Hidalgo: Dímelo tú. / Pasiega: Yo soy cero. / Beata: Háblale con claridad / pues sabes todo el suceson.

110. Estos dos últimos versos se omiten tanto en la partitura como en el apunte teatral.

111. Esta indicación no figura en el libreto, y proviene de la partitura: Allegro no mucho (3/4). 
MARÍA JESÚS GARCÍA GARROSA

JOAQUINA COMELLA, AUTORA DESCONOCIDA DE LOS LIBRETOS PARA SIETE TONADILLAS...

PASIEGA.

HIDALGO.

BEATA.

PASIEGA.

HIDALGO.

[f 6r] BEATA.

PASIEGA.

HIDALGO.

PASIEGA. ${ }^{113}$

HIDALGO.

BEATA.

PASIEGA.

LOS 3 .

PASIEGA y BeATA.

[f 6v] Sale PAsIEGA.

BEATA.

HIDALGO.

BEATA.
Yo tan solo decir puedo

145 que a mí el criarlo me pagan.

¡Pobrecito don Venancio, qué petardo ${ }^{112}$ te jugaban!

¿No te lo entregó una noche un señor en esta casa?

150 Por más señas que vmd. entonces estaba fuera de casa.

¡Fuera o dentro, don Venancio qué petardo te pegaban!

¿Los padres de este muchacho no suelen venir a casa? Yo a la madre no la he visto, pero al padre veces varias. ¡Con el padre, don Venancio qué petardo te pegaban!

160 Ya queda vmd. disculpada, ya se puede vmd. casar, que las dudas que tenía ya las puede vmd. tragar. ¡Un demonio!

¡Picarona!

165 Si no abona ${ }^{114}$ [a] su persona lo volveré a relatar ${ }^{115}$. Semejante villanía quién pudiera imaginar. (Llaman) Pero llaman a la puerta, el que vino ve a mirar.

\section{Parola}

Ocho cuartos. (Sale con una carta) De la Mancha

vamos a ver quién me escribe.

Ella lee muy contenta, y de gozo se sonríe.

$[\text { Música }]^{116}$

175 ¡Oh, qué plácido momento!

112. Petardo: "Se toma por estafa, o engaño que se hace, pidiendo prestado, y no volviéndolo». 113. La partitura marca a partir de este verso un cambio de tempo y compás: Allegro (6/8). También el libreto indica esta variación con el signo $=$.

114. Abonar a otro: "Salir por su fiador, responder por él».

115. "volverelu a relatar", dicen la partitura y el apunte, acentuando los rasgos vulgares del habla de la pasiega.

116. Esta indicación no figura en el libreto, y proviene de la partitura: Allegro (6/8). 
HIDALGO.

Lea vmd. sin más demora.

No se pudo en mejor hora el enlace publicar.

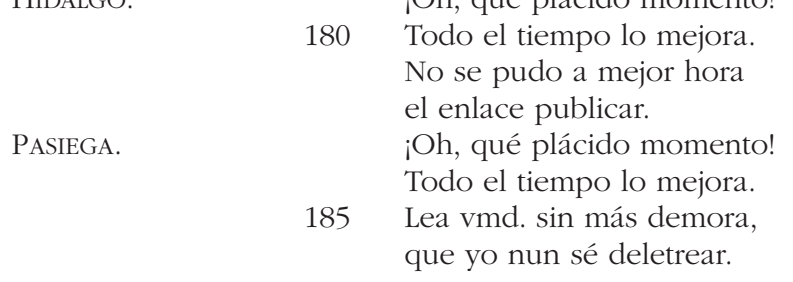

$$
[\text { Parola }]^{117}
$$

[f 7r] Hidalgo, lee.

"Querida hermana: A beneficio de los ruegos de un poderoso, han cedido los padres de mi marido, don Antonio Sandoval, y se ha publicado en Manzanares nuestro matrimonio. Cuanto antes pasaremos a recoger el fruto de nuestra terneza y a darte las gracias por tu sigilo y cuidado».

HIDALGO

BEATA.

PASIEGA. ¡Beata de mis entrañas, dame los brazos corriendo! Quítese de mi presencia. Aquí estoy yo en su defecto, y verá cómo le crío los hijos como terneros.

\section{Final ${ }^{118}$}

HIDALGO

Vamos, vamos, beata mía, nuestro enlace a celebrar.

[f 7v] BEATA.

Aunque no lo merecía, no me quiero hacer rogar.

PASIEGA. Mal me ha salido el engaño, y me voy a repelar ${ }^{119}$.

LOS $3 .{ }^{120}$ Cuánto yerra el juicio humano 200 en los conceptos que forma, lo que servirá de norma al infame detractor. ¡Viva, viva la inocencia, la prudencia y el candor!

117. Esta indicación no figura en el libreto, pero sí en la partitura y el apunte.

118. Allegro moderato (4/4).

119. Repelar: "Sacar o arrancar el pelo».

120. Allegro. Este cambio a un tempo más rápido en el trío final subraya la moraleja del texto. 
APÉNDICE 2

Solicitudes de Licencia de Representación

\section{El novio y las dos hermanas}

Don Blas Laserna y doña Joaquina Comella con el mayor respeto dicen: Que habiendo compuesto la tonadilla a tres titulada El novio y las dos hermanas para cantarse en el coliseo de la calle de la Cruz.

Suplican a V. S. se sirva concederles las licencias necesarias. Madrid, 21 de agosto de 1800 .

[Fdo.] Blas Laserna - Joaquina Comella

Sr. Vicario Eclesiástico de Madrid.

De orden de V. S. he visto los adjuntos manuscritos titulados Tonadilla a 3 El novio y las dos hermanas, Sainete nuevo Los hidalgos chasqueados, en cuyos contextos, omitiendo lo rayado en el primero, no he advertido cosa alguna que se oponga a nuestra santa fe, buenas costumbres, regalías de S. M., leyes del reino, ni otro defecto que deba impedir su representación. Madrid, 21 de agosto de 1800.

B. L. M. de V. S. su atentísimo capellán.

[Fdo.] Pedro Estala

[Se autoriza la representación omitiendo lo rayado el 22 de agosto de 1800]

\section{El marido indiscreto}

Sr. Juez Eclesiástico.

Don Blas de Laserna y doña Joaquina Comella con el mayor respeto dicen: Que habiendo compuesto la tonadilla a tres El marido indiscreto para cantarla en el coliseo de la calle de la Cruz.

Suplican a V. S. se sirva concederles la licencia necesaria, gracia que esperan de la justificación de V. S. Madrid, 2 de septiembre de 1800.

[Fdo.] Blas Laserna - Joaquina Comella

Sr. Vicario Eclesiástico de Madrid.

He visto de orden de V. S. la tonadilla intitulada El marido indiscreto, la cual no juzgo digna de exponerse en el teatro por su mal ejemplo, que sería muy escandaloso.

Asimismo me parece indigno de representarse el sainete intitulado El padre forzado, por ser un conjunto de las groserías más necias y de las escenas más escandalosas.

Dios guarde a V. S. muchos años. Madrid, 9 de septiembre de 1800.

B. L. M. de V. S. su más rendido servidor y capellán.

[Fdo.] Pedro Estala 


\section{El novio simple}

Sr. Vicario.

Don Blas Laserna y doña Joaquina Comella con el mayor respeto dicen: Que habiendo compuesto la tonadilla a tres titulada El novio simple para cantarse en el coliseo de la calle de la Cruz.

Suplican a V. S. se sirva concederles la licencia necesaria. Madrid, 17 de septiembre de 1800 .

[Fdo.] Blas Laserna - Joaquina Comella

Sr. Vicario Eclesiástico de Madrid.

He visto de orden de V. S. la tonadilla adjunta intitulada El novio simple, y no hallo en ella cosa contraria a la religión, buenas costumbres y regalías de S. M., por lo cual me parece no hay inconveniente para que se represente.

Dios guarde a V. S. muchos años. Madrid, 20 de septiembre de 1800.

B. L. M. de V. S.

Su muy afectísimo servidor y capellán.

[Fdo.] Pedro Estala

[Se autoriza la representación el 20 de septiembre de 1800]

\section{El majo y los dos hermanos}

Sr. Vicario Eclesiástico.

Don Blas de Laserna y doña Joaquina Comella con el mayor respeto dicen: Que habiendo compuesto la tonadilla a tres titulada El majo y los dos hermanos para cantarse en el coliseo de la calle de la Cruz.

Suplican a V. S. se sirva concederles las licencias necesarias, gracia que esperan de la justificación de V. S. Madrid, 30 de septiembre de 1800.

[Fdo.] Blas Laserna - Joaquina Comella

Sr. Vicario Eclesiástico de Madrid.

De orden de V. S. he visto la adjunta pieza manuscrita titulada Tonadilla a tres El majo y los dos hermanos, en cuyo contexto no he advertido cosa alguna que se oponga a nuestra santa fe, buenas costumbres, regalías de S. M., ni leyes del reino. Madrid, 6 de octubre de 1800.

B. L. M. de V. S.

Su atento capellán.

[Fdo.] Pedro Estala

[Se autoriza la representación el 6 de octubre de 1800] 
JOAQUINA COMELLA, AUTORA DESCONOCIDA DE LOS LIBRETOS PARA SIETE TONADILLAS...

5. 6. 7. La pasiega y el hidalgo, El marido pesado, La elección de moda

Don Blas Laserna con el mayor respeto dice: Que habiendo puesto en música las tres tonadillas adjuntas a 3 tituladas la 1. ${ }^{a}$ La pasiega y el hidalgo, 2. ${ }^{a}$ El marido pesado, 3. ${ }^{\mathrm{a}}$ La elección de moda, y compuesto las letras doña Joaquina Comella (ya difunta), para cantarse en el coliseo de la calle de la Cruz.

Suplica a V. S. se sirva concederle la licencia necesaria, gracia que espera merecer de la justificación de V. S. Madrid y 2 de diciembre de 1800.

[Fdo.] Blas Laserna

Sr. Vicario Eclesiástico de Madrid.

De orden de V. S. he visto las adjuntas piezas manuscritas tituladas Tonadilla a 3 El marido pesado, Tonadilla a 3 La pasiega y el hidalgo, Tonadilla a 3 La elección de moda, en cuyos contextos no he advertido cosa alguna que se oponga a nuestra santa fe, buenas costumbres, regalías de S. M., leyes del reino. Este es mi parecer salvo el superior de V. S. Madrid, 10 de diciembre de 1800.

B. L. M. de V. S. su atento capellán.

[Fdo.] Pedro Estala

[No hay aprobaciones; solo nota de que se envía a censura de Estala el 3 de diciembre]

(Archivo Histórico Diocesano de Madrid, Caja 9187) 


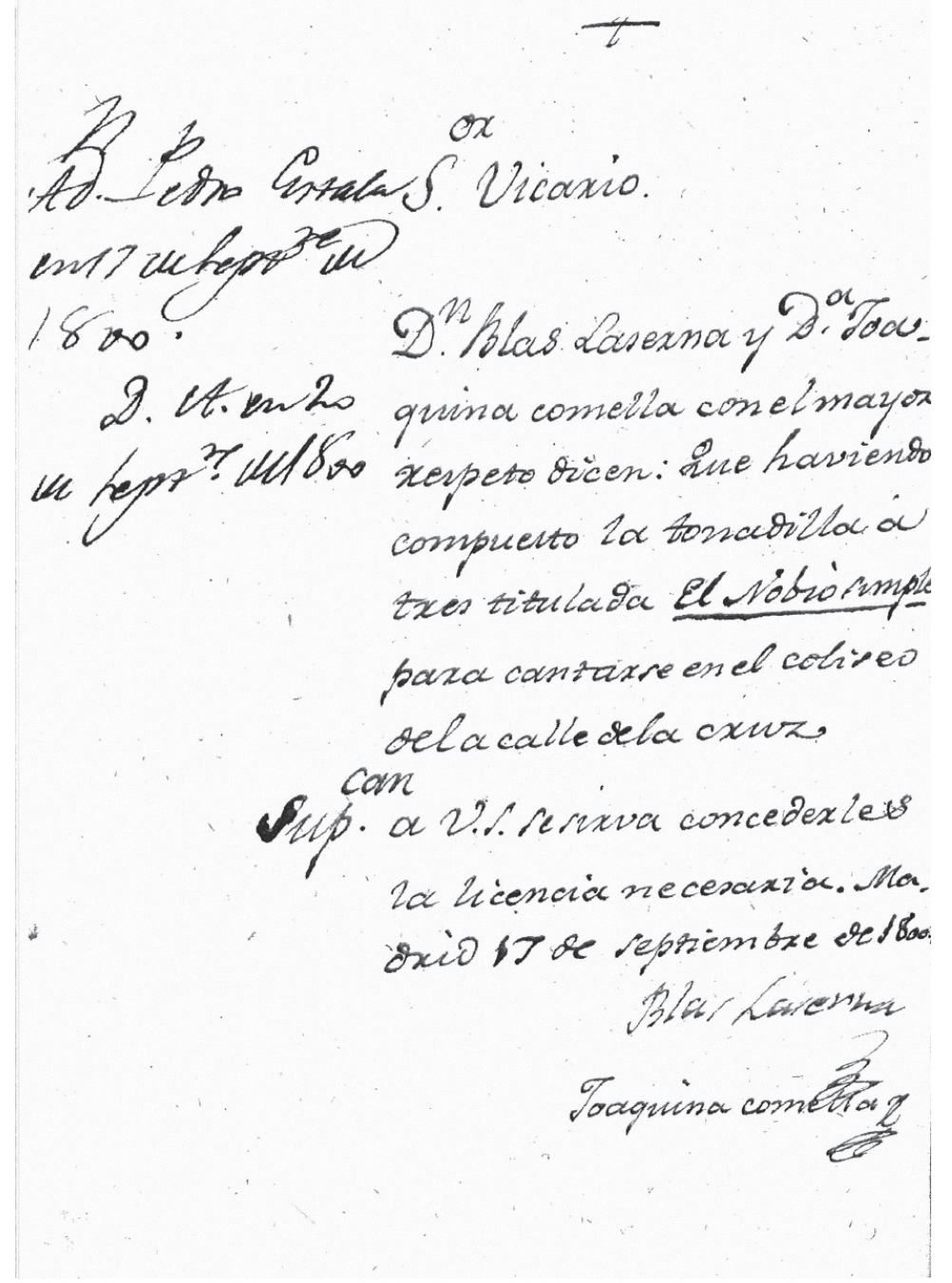

Figura 1. Solicitud de licencia de representación de la tonadilla El novio simple. AHDM, Caja 9187 


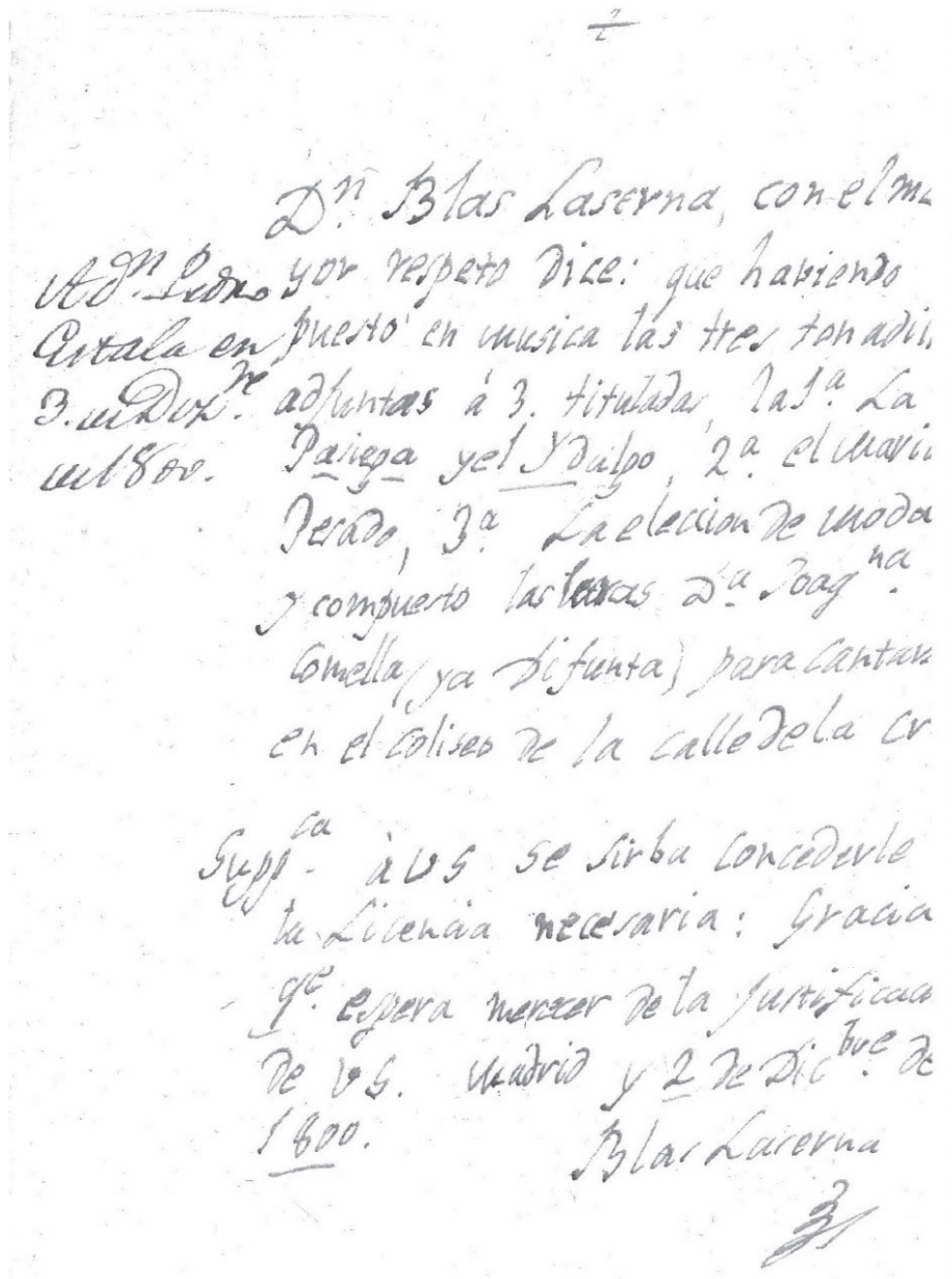

Figura 2. Solicitud de licencia de representación de las tonadillas La pasiega y el hidalgo, El marido pesado y La elección de moda. AHDM, Caja 9187 


\section{BIBLIOGRAFÍA}

ANDIOc, René y Coulon, Mireille. Cartelera teatral madrileña del siglo XVIII (1708-1808). Madrid: Fundación Universitaria Española, 2008, 2. ${ }^{\text {a }}$ ed., 2 vols.

Angulo EgeA, María. «Una tonadilla escénica. La Anita de Joaquina Comella, con música de Blas de Laserna». Salina, 12, 1998, pp. 77-99.

Angulo EgeA, María. "Luciano Francisco Comella (1751-1812), el melólogo y Doña Inés de Castro". En Comella, Luciano Francisco y Laserna, Blas de. Doña Inés de Castro, escena trágico lírica. Ed. ANgulo Egea, María, Labrador López de AzCona, Germán y GarCía MarTínez, J. Daniel. Salamanca: GES XVIII-Ediciones Amnesia, 2005, pp. 9-28.

Angulo Egea, María. Luciano Francisco Comella (1751-1812). Otra cara del teatro de la Ilustración. Alicante: Universidad de Alicante, 2006.

BARBIERI, Francisco A. Documentos sobre música española y epistolario. Ed. CASAREs, Emilio. Madrid: Fundación Banco Exterior de España, 1988.

BOlufer, Mónica. Mujeres e Ilustración. La construcción de la feminidad en la España del siglo XVIII. Valencia: Institució Alfons el Magnànim, 1998.

Comella, Joaquina. La Anita. Ed. DoméneCh, Fernando. En Teatro breve de mujeres. Siglos XVII-XX. Madrid: Asociación de Directores de Escena de España, 1996, pp. 116-135.

Cotarelo y Mori, Emilio. Iriarte y su época [1897]. Santa Cruz de Tenerife: Artemisa, 2006.

COTARElo y Mori, Emilio. Isidoro Máiquez y el teatro de su tiempo [1902]. Madrid: Asociación de Directores de Escena, 2009.

DoméNeCH, Fernando. "La Anita". En Teatro breve de mujeres. Siglos XVII-XX. Madrid: Asociación de Directores de Escena de España, 1996, pp. 104-113.

DomÉNECH, Fernando. «Comella, Joaquina». En Hormigón, Juan Antonio (dir.). Autoras en la historia del teatro español (1500-1994). Volumen I (Siglos XVII-XVIII-XIX). Madrid: Asociación de Directores de Escena de España, 1996, pp. 433-434.

García de Villanueva Hugalde y Parra, Manuel. Origen, épocas, y progresos del teatro español. Madrid: Gabriel de Sancha, 1802.

García GARROSA, María Jesús. "La escuela del matrimonio: los conflictos conyugales en el teatro español de finales del siglo XVIII». Bulletin of Hispanic Studies, 2015, 92.4, pp. 367-383.

GómeZ, Julio. «Don Blas de Laserna. Un capítulo de la historia del teatro lírico español visto en la vida del último tonadillerom. En ARrese, José Luis. Biblioteca de corellanos ilustres. Tomo V. El músico Blas de Laserna. Corella, 1952, pp. 119-163 y 165-185.

GonzÁlez Troyano, Alberto. «En torno a la tonadilla escénica». En Álvarez BARRIENTOS, Joaquín y Checa Beltrán, José (eds.). El siglo que llaman ilustrado. Homenaje a Francisco Aguilar Piñal. Madrid: CSIC, 1996, pp. 487-491.

GRINSTEIN, Julia Bordiga. "Panorama de la dramaturgia femenina española en la segunda mitad del siglo XVIII y principios del XIX». Dieciocho, 2002, 25.2, pp. 195-218.

Herrera Navarro, Jerónimo. Catálogo de autores teatrales del siglo XVIII. Madrid: Fundación Universitaria Española, 1993.

Herrera NAVARro, Jerónimo. «Precios de piezas teatrales en el siglo XVIII (Hacia los derechos de autor)». Revista de Literatura, 1996, LVIII, 115, pp. 47-82.

HUERTAS, Eduardo. "La tonadilla escénica». En Teatro musical en el Madrid ilustrado. Madrid: Avapiés, 1989, pp. 53-80.

LE GUIN, Elisabeth. "Hacia una revalorización de la tonadilla tardía». En Álvarez BARRIENTos, Joaquín y Lolo, Begoña (eds.). Teatro y Música en España: los géneros breves en 
la segunda mitad del siglo XVIII. Madrid: Universidad Autónoma de Madrid-Consejo Superior de Investigaciones Científicas, 2008, pp. 183-195.

Lolo, Begoña. "La tonadilla escénica, ese género maldito". Revista de Musicología, 2002, $\mathrm{XXV},{ }^{\circ}{ }^{\circ}$ 2, pp. 439-469.

Memorial literario, tomo XV, septiembre 1787.

PAlacios Fernández, Emilio. La mujer y las letras en la España del siglo XVIII. Madrid: El Laberinto, 2002.

ReAl RAmos, César y AlCalde Cuevas, Luis. «La tonadilla: un capítulo en la historia del espectáculo del siglo XVIII». En KLEINERTZ, Rainer (ed.). Teatro y música en España (siglo XVIII). Kassel: Reichenberger, 1996, pp. 125-144.

Sánchez [Barbero], Francisco. Principios de Retórica y Poética. Madrid: Imprenta de la Administración del Real Arbitrio de Beneficencia, 1805.

SERRANO y SANZ, Manuel. Apuntes para una biblioteca de escritoras españolas desde el año 1401 al 1833. I. Primera parte [1903]. Madrid: Atlas, 1975.

SuBIRÁ, José. La tonadilla escénica. Madrid: Tipografía de Archivos, 1928-1929, 3 vols.

SUBIRÁ, José. La tonadilla escénica. Sus obras y sus autores. Madrid: Labor, 1933.

SuBIRÁ, José. Un vate filarmónico: Don Luciano Comella. Madrid: Real Academia de Bellas Artes de San Fernando, 1953. 
